(36)

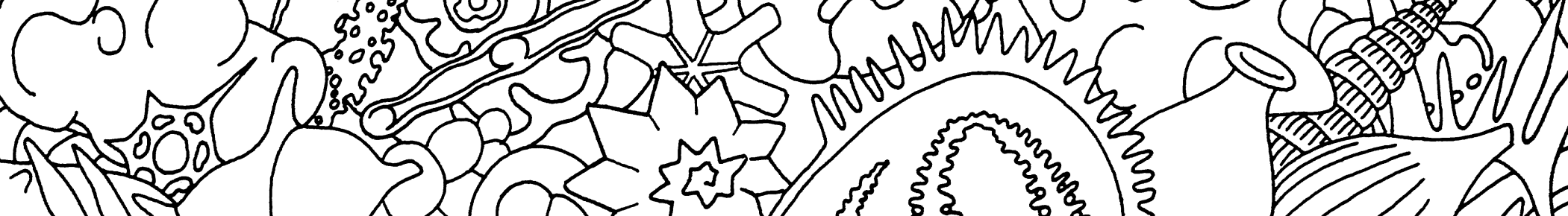
No Whe
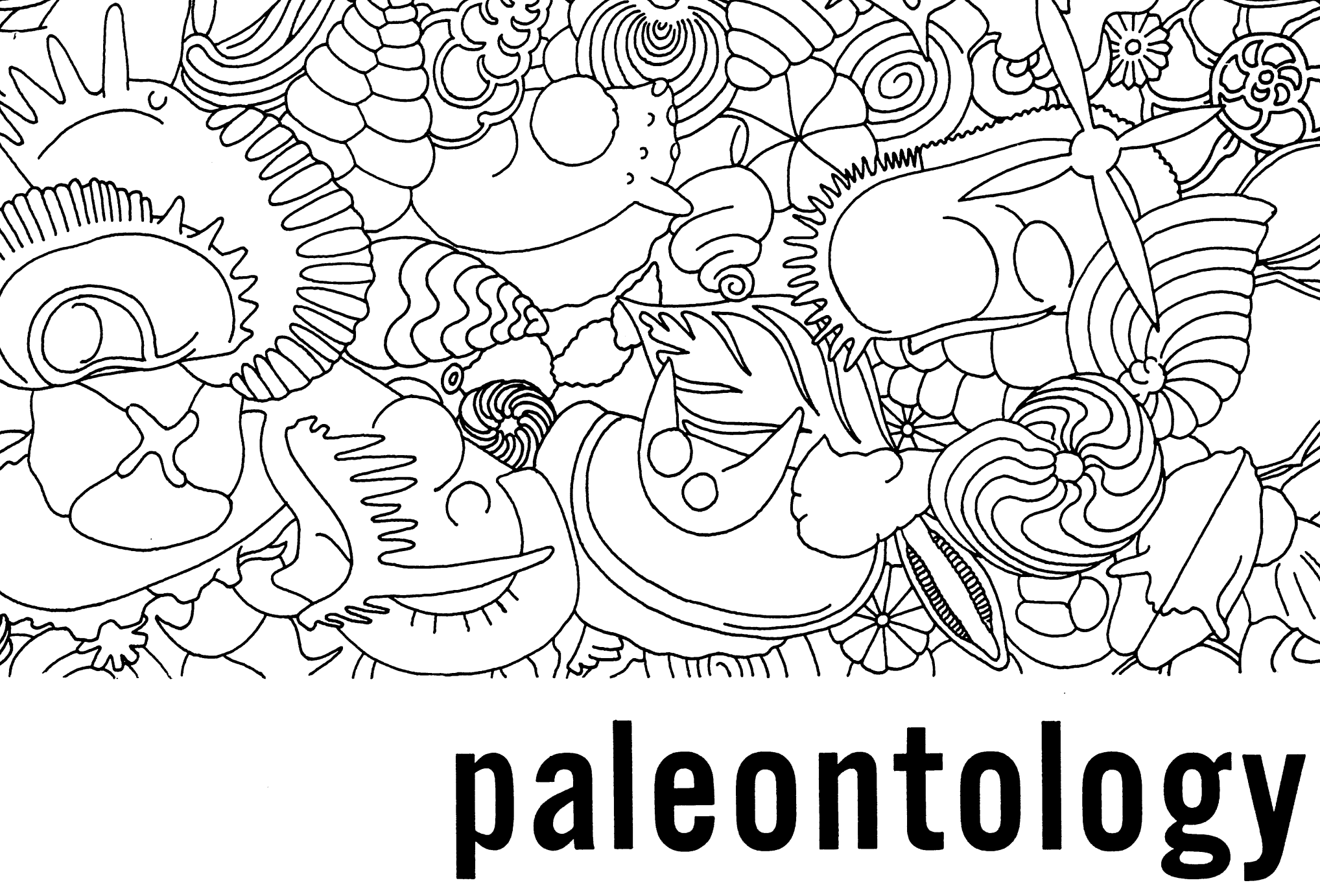

volume 4 
PUBLISHED BY:

Department of Micropaleontology

American Museum of Natural History

Central Park West at Seventy-Ninth Street

New York 24, New York

\section{pale ont ology}

volume 4

number 2

april

1958 
Abstract: Although hollinid ostracods from the Middle Devonian Jeffersonville limestone at the Falls of the Ohio have been known for many years, a detailed study reveals a new genus, Flaccivelum, and fifteen new species, belonging to the genera Abditoloculina, Ctenoloculina, Hollina, Hollinella, and Subligaculum. Nine other species, belonging to the genera Abditoloculina, Adelphobolbina, Flaccivelum, Hollina, and Hollinella, have been previously described. Many of the species of Abditoloculina are closely related, but can be distinguished by the number of loculi in the female.

\title{
Middle Devonian hollinid ostracods from the Falls of the Ohio
}

\author{
ROBERT V. KESLING AND REX M. PETERSON \\ Museum of Paleontology \\ University of Michigan \\ Ann Arbor, Michigan
}

\section{INTRODUCTION}

Excellently preserved fossils occur in the Middle Devonian Jeffersonville limestone at the famous locality known as the Falls of the Ohio, on the Ohio River between Louisville, Kentucky, and Jeffersonville, Indiana. In small pockets at the surface, naturally weathered Bryozoa, ostracods, and other small fossils are concentrated. For years, these pockets provided rich material to many museums. Now they are scarce. Although the microfossils are silicified and very brittle, most are completely weathered from the matrix and require very little cleaning. The ostracod fauna of the Jeffersonville limestone includes many families in addition to the Hollinidae, which we have made the subject of this study. The ostracods described here are from a sample given to the Museum of Paleontology of the University of Michigan more than a quarter of a century ago by Dr. R. S. Bassler, to whom we express our profound thanks.

The hollinid ostracods described here include seven genera and twenty-three species, of which one genus and fifteen species are new. In addition, there are four males of the genus Abditoloculina that are designated only by letter, for lack of sufficient evidence to assign them to species with the corresponding females.

All specimens figured in this paper are catalogued and deposited in the Museum of Paleontology of the University of Michigan.

STRATIGRAPHY

The Jeffersonville limestone is of Middle Devonian age and is correlated with the Onondaga limestone

of New York. It has been well described in the region of the Falls of the Ohio by Campbell (1942). It overlies the Silurian Louisville dolomite and is overlain by rocks of the Middle Devonian Hamilton group. On the Indiana side of the Falls at Jeffersonville, twenty-nine feet of the Jeffersonville limestone is exposed and is overlain successively by the Silver Greek and Beechwood formations. Here the Jeffersonville limestone consists of nine feet of coral zone with Meristella nasuta, ten feet of "Spirifer" gregarius zone, and ten feet of "Spirifer" acuminatus zone. The last is a thick-bedded, white to gray limestone with several cherty layers; the thin basal layer is filled with ostracods and bryozoa. It was from this bed that Dr. Bassler collected the material yielding the ostracods described here.

\section{PREVIOUS WORK}

Middle Devonian hollinid ostracods from the eastern United States have been described by Jones (1890), Ulrich (1890-1891, 1900), Ulrich and Bassler (1908), Coryell (1928), Coryell and Malkin (1936), Swartz (1936), Warthin (1934), Bassler (1941), Stover (1956), and Kesling and his students during the past several years.

Ulrich's excellent works (1890-1891, 1900) included some of the common hollinids from the Falls of the Ohio. However, a surprisingly large number of hollinid ostracods remained undiscovered. Perhaps additional species will yet be found when more material is worked over. 
TABLE 1

KEY FOR IDENTIFICATION OF FEMALE VALVES OF Abditoloculina SPECIES FROM THE JEFFERSONVILLE LIMESTONE

\begin{tabular}{|c|c|c|c|c|c|c|}
\hline \multirow{2}{*}{$\begin{array}{c}\text { Number } \\
\text { of } \\
\text { loculi }\end{array}$} & \multicolumn{2}{|c|}{$\begin{array}{l}\text { Frill with thick lateral rim; } \\
\text { L3 a bulb }\end{array}$} & \multicolumn{2}{|c|}{$\begin{array}{l}\text { Frill with thin distal rim; } \\
\text { L3 a bulb }\end{array}$} & \multicolumn{2}{|c|}{$\begin{array}{l}\text { Frill plain, without rim; } \\
\text { L3 a low lobe }\end{array}$} \\
\hline & $\begin{array}{c}\text { Loculi with } \\
\text { lunate } \\
\text { outer lip }\end{array}$ & $\begin{array}{l}\text { Loculi with } \\
\text { small } \\
\text { simple rim }\end{array}$ & $\begin{array}{c}\text { No } \\
\text { posterior } \\
\text { nodes }\end{array}$ & $\begin{array}{c}\text { Two } \\
\text { posterior } \\
\text { nodes }\end{array}$ & $\begin{array}{l}\text { Ll lobate, } \\
\text { dorsally } \\
\text { projecting }\end{array}$ & $\begin{array}{l}\text { L1 small, } \\
\text { not above } \\
\text { hinge line }\end{array}$ \\
\hline 7 & & & A. insolita & A. binodata & & \\
\hline 8 & A. palpebrata & & & & & A. repanda \\
\hline 9 & A. obesivelata & A. fundiornata & & & A. prominens & A. pusilla \\
\hline 10 & A. clavicavosa & & & & A. eminens & A. pumila \\
\hline 11 & & & & & & A. cavimarginata \\
\hline
\end{tabular}

SYSTEMATIC DESCRIPTIONS

\section{Order OSTRACODA}

\section{Family HOLLINIDAE Swartz, 1936}

\section{Genus Abditoloculina Kesling, 1952}

Type species: Abditoloculina insolita Kesling, 1952, pp. 765, 767-768, pl. 111, figs. 7-14, by original designation.

Diagnosis: Hollinid genus with each valve trilobate, having a distinct lobe, knob, or bulb for L3; the posterior part of each valve flat to gently convex, without any development of an L4; each female valve with loculi and spurs; and each male valve with velate spurs and a divided velate ridge, the first part from the anterior region onto the front spur and the second part from below the front spur to the posteroventral region.

Remarks: Species of this genus are known only from Middle Devonian strata. Some undescribed species occur in the Traverse group (Hamilton) of Michigan.

Many of the ostracods assigned to Abditoloculina from the Jeffersonville limestone are closely related. We have distinguished several solely on the basis of the number of loculi in the female. We should be extremely chary of this criterion were it not for the fact that the loculi in the 8-loculate, 9-loculate, and 10-loculate ostracods are differently spaced. The presence of another loculus is not a simple supernumerary addition at the posterior end of the frill; instead, all loculi are smaller and crowded together, so that each loculus lies in a different position with respect to the lobes, sulci, and spurs. Loculi are distinct, complex structures, and their arrangement, in our opinion, cannot be regarded as fortuitous; therefore, the ostracods with eight, nine, and ten loculi belong to different species. In addition, in such closely related species as Abditoloculina palpebrata, Abditoloculina obesivelata, and Abditoloculina clavicavosa, the ostracods with different numbers of loculi differ slightly in lobation and development of spurs.

Unfortunately, several of the species are so closely related that they can be separated only on the characteristics of the females. Males of these species are here designated only by letter; the corresponding females are not known with certainty. Abditoloculina armata, described from a male valve by Ulrich, is here retained as a separate species because we are not sure whether it is a male of Abditoloculina clavicavosa, Abditoloculina fundiornata, or Abditoloculina cavimarginata, or whether it is a valid species of which the female dimorph has not been discovered.

It appears that Jeffersonville time was an age of great specific proliferation of Abditoloculina. The characteristics showing most variation are the shape of the frill, the spurs, the size of $\mathrm{Ll}$ and L3, and the number of loculi. As would be expected, during such rapid evolution all characteristics did not respond simultaneously or to the same degree. Lobation seems to have been the most conservative characteristic and the number of loculi the least conservative, inasmuch as some species vary only slightly in their lobation but have different numbers and spacing of loculi.

\section{Abditoloculina binodata Kesling and Peterson, new species \\ Plate 1, figures 42-47}

Diagnosis: Small Abditoloculina species with each female valve having a thin distal rim on the frill, two posterior nodes, seven loculi, and the anterior spur on the convexity of the frill marking the third loculus.

Female: Valve elongate subelliptical to subpyriform in lateral view. Hinge line straight, anterior border round, ventral border gently curved, and posterior border 
subround. Anterior and ventral parts of free edge concealed by the frill.

Trilobate; $\mathrm{Ll}$ a low; elongate lobe near the anterior corner; L2 a conspicuous knob separated from the dorsal border by about one-sixteenth of the height of the valve, slightly smaller than L3; and L3 bulbous, with high relief, extending above the hinge line, bearing a short posterodorsal spine, and having a diameter equal to about one-third the height of the valve. Posterior part of the valve nearly flat, only slightly convex. Two small, conspicuous knob-like nodes on the posterior part of the valve, of about equal size and shape; the dorsal one tangent to the hinge line near the posterior corner, and the ventral one below it at about the same height as the dorsal edge of the rear spur. Sl shallow, separating Ll and L2; S2 moderately deep, S-shaped, extending from the hinge to the frill, passing between L2 and L3 and around the anterior end of the rear spur.

Spurs subconical, posteriorly directed. Anterior spur much smaller than posterior, extending onto the dorsal part of the convexity of the frill marking the third loculus. Posterior spur curved, its base located below the front edge of L3 and above the frill (approximately between the convexities marking the fifth and sixth loculi).

Frill with a narrow, delicate distal rim, and distinct lateral ovate convexities marking the positions of the loculi. Seven nearly round loculi. Each loculus rimmed by a narrow crest. Submarginal ridge small, low, bearing closely spaced, very small papillae. As seen in anterior view, the partitions between the loculi have their ventral surfaces set at an angle of about 70 degrees to the contact margin of the valve.

Lateral surface granular. Anterior and posterior cardinal angles about 120 and 130 degrees.

Dimensions of holotype, an almost complete left valve: Length $0.90 \mathrm{~mm}$.; height $0.52 \mathrm{~mm}$.; width (exclusive of spurs) $0.24 \mathrm{~mm}$.

Remarks: This species closely resembles the type species, Abditoloculina insolita Kesling (1952, pp. 767-768, pl. 111, figs. 7-14), and Abditoloculina pulchra Kesling (1955, pp. 274-276, pl. 1, figs. 1-19). It differs from Abditoloculina insolita (see Table 1) in having a larger L2, which is a knob rather than a node; the anterior spur extending onto the frill convexity marking the third loculus rather than the second; a smaller and less curved posterior spur; and two nodes on the posterior part of the valve instead of a single small tubercle between L3 and the posterior corner. Abditoloculina binodata differs from Abditoloculina pulchra, from the Hamilton group, in having seven instead of eight loculi, a small posterodorsal spine on L3, posterior nodes, and a simple conical anterior spur rather than a dumbellshaped structure.

The name of this species is derived from the Latin $b i$ ("two-, double") and nodus, m. ("a node"), and refers to the two posterior nodes on the valve.
Types: Holotype, an almost complete female left valve, no. 34679. Paratype, an incomplete female right valve, no. 34680 .

\section{Abditoloculina cavimarginata (Ulrich) Plate 1, figures 19-21}

Ctenobolbina cauimarginata ULRICH, 1900 (in part), p. 182, pl. 8, figs. 8-9 (not fig. 7). - Ellis and Messina, 1952 (in part), unnumbered page, figs. 8-9 (not fig. 7).

Hollina cavimarginata (Ulrich). - ULRICH AND BASSLER, 1908 (in part), p. 315, pl. 42, figs. 11-12 (not fig. 10). - GRABAU AND SHIMER, 1910 (in part), p. 357, text-fig. $1660 \mathrm{w}^{\prime}, \mathrm{x}$ (not fig. 1660w). - Bassler and Kellett, 1934 (in part), p. 329. - Swartz, 1936, p. 552, pl. 80, fig. 3c. - Warthin, 1937 (in part), card 72, figs. 8-9 (not fig. 7).

Abditoloculina cavimarginata (Ulrich). - KESLING, 1952 (in part), p. 767. - PoKorný, 1954 (in part), text-fig. 531 (lower two figures only).

Diagnosis: Large Abditoloculina species with each female valve having an almost flat frill without a lateral rim, a small L1, a low lobate L3, and eleven loculi.

Supplementary description of female: Valve subelliptical to subpyriform in lateral view. Hinge line straight. Anterior and ventral borders round, without indentations to mark the positions of the loculi. Posterior border gently curved.

Trilobate; Ll small, not projecting above hinge line, L2 an ovate knob, and L3 an ovate lobe extending slightly above the hinge line. Posterior part of valve low, continuous with a broad diagonal ridge extending below L3 to the posterior spur. S2 narrow and rather deep, extending from hinge line to the ventral border. Posteroventral part of valve flat, separated from the slightly arched posterior part of the valve by a broad semisulcus.

Anterior spur knob-like, essentially the same size as L2, without a sharp projection. Posterior spur massive, with a thick base and a blunt posteroventral tip.

Frill plain, flat, continuous with the lateral surface of the valve. As seen in ventral view, eleven subovate to subtriangular loculi. Partitions between loculi meeting the frill with smooth junctions; each partition with very faint lateral ridges, forming rims of the loculi, and shallow, indistinct transverse grooves; the narrowest part of each partition about half as wide as the adjacent loculus. Submarginal structure proximal to loculi, level with partitions between the loculi. Narrow marginal ridge, separated from submarginal structure by a very narrow groove or channel.

Lateral surface smooth to finely granular. Corners somewhat round; anterior and posterior cardinal angles about 120 and 135 degrees, respectively.

Dimensions of topotype, no. 34671 , a right valve: Length $1.08 \mathrm{~mm}$.; height $0.69 \mathrm{~mm}$; width (including spur) $0.42 \mathrm{~mm}$. 
Remarks: An examination of the syntypes (labeled "cotypes"), U. S. National Museum, no. 41495, shows that the original description and illustrations of Abditoloculina cavimarginata (Ulrich) were composites of two species. As lectotype we here designate the specimen illustrated by Ulrich (1900) in pl. 8, figs. 8-9. The other specimen (Ulrich's pl. 8, fig. 7) belongs to a new species, described below as Abditoloculina obesivelata.

Abditoloculina cavimarginata resembles Abditoloculina pumila, n. sp., but differs in having eleven loculi instead of ten, a much thicker and more massive spur, larger and more convex lobes, and thicker partitions between the loculi.

Illustrated specimen: Topotype, a female right valve, no. 34671 .

\section{Abditoloculina clavicavosa Kesling and Peterson, new species \\ Plate 1, figures 10-12}

Diagnosis: Large Abditoloculina species with each female valve having a thick lateral rim on the frill, a lunate outer lip on each loculus, and ten loculi.

Female: Valve large, subelliptical to suboval in lateral view. Posterior part of valve broken off in holotype and only specimen. Hinge line straight, anterior border subround, and ventral border gently curved. Most of free border hidden by frill.

Trilobate; Ll a small knob at the anterior corner, with a long posterodorsal tubercle extending above the hinge line; L2 large, bulbous, larger than L1 or L3; and L3 bulbous, slightly smaller than L2 but larger than L1, extending slightly above hinge line. S1 very narrow, separating Ll and L2; S2 deep, long, sinuous, extending from hinge line to the lateral rim of the frill, passing between L2 and L3 and between the two spurs. Low ridge, broad, slanting, connecting the posterodorsal part of the valve to the rear spur and rising above the flat posterior part of the frill.

Spurs distinct, curved posteriorly. Anterior spur smaller, its base sloping anteroventrally, its tip bent sharply backward. Posterior spur larger, subconical, directed outward and slightly backward.

Frill with a thick lateral rim extending sharply outward, nodose in the anterior part, set close under the spurs. Ventral surface of lateral rim and partitions between the loculi ornamented with small, closely spaced longitudinal crests. Ten deep loculi, each suboval to keyhole-shaped, surrounded by a distinct rim. Rim narrow except in distal part, there enlarged to form a lunate outer lip of the loculus. Distally, each partition about half as wide as the adjacent loculus; proximally, much wider than the loculus. Marginal ridge separated by a narrow channel from the loculate part of the valve. Lateral surface granular, covered with irregular, very shallow depressions, like dents.
Dimensions of holotype, a broken left valve: Height $0.73 \mathrm{~mm}$; width (including spur) $0.47 \mathrm{~mm}$. Length estimated to have been 1.15 to $1.20 \mathrm{~mm}$.

Remarks: This species resembles Abditoloculina obesivelata, Abditoloculina fundiornata, and Abditoloculina palpebrata, described below, in having a thick lateral rim on the frill; it can be distinguished from all of them by its greater number of loculi. As shown in Table 1, Abditoloculina eminens and Abditoloculina pumila also have ten loculi, but both of them have a plain frill without any lateral rim.

The name of this species is derived from the Latin clavis, f. ("key"), and cavum, n. ("a hole, cavity"), and refers to the keyhole-shaped loculi.

Type: Holotype, a broken female left valve, no. 34667.

\section{Abditoloculina eminens Kesling and Peterson, new species \\ Plate 1, figures 25-27}

Diagnosis: Large Abditoloculina species with each female valve having an almost flat frill without a lateral rim, a large linguiform L1, a low lobate L3, ten loculi, a low node-like anterior spur, and a massive and blunt posterior spur.

Female: Valve subpyriform in lateral view. Hinge line straight, anterior and ventral borders round, and posterior border subround. Posterior end acuminate. Frill extending very little beyond the free edge. Positions of loculi not apparent in lateral view of the frill.

Trilobate; Ll a large, linguiform lobe, gently convex, extending well above the hinge line; L2 a conspicuous but low, vertically elongate lobe extending nearly to the dorsal border; and L3 a very low, poorly defined, small lobe extending slightly above the hinge line. Posterior part of the valve very gently convex, nearly flat. S1 a short shallow groove between L1 and L2; S2 a deeper groove, sinuous, passing between L2 and L3 and between the spurs.

Anterior spur a low lobe ventral and slightly anterior to L2. Posterior spur massive, blunt, directed outward and backward.

Frill flat, without rim of any kind. Ten subovate loculi. Partitions between loculi bearing faint transverse grooves, their narrowest parts about half as wide as the loculi. A shallow groove forming the channel between the submarginal ridge and the proximal structure bounding the loculi. Submarginal ridge low, with faint papillae. Surface smooth to very finely granular.

Dimensions of holotype, an incomplete left valve: Height $0.67 \mathrm{~mm}$; width (including spur) $0.39 \mathrm{~mm}$. Estimated length $1.05 \mathrm{~mm}$.

Remarks: This is the first species of Abditoloculina discovered in which Ll is linguiform and much more 
prominent than L3. It most closely resembles Abditoloculina prominens, from which it differs in having a shallower S2, a blunter posterior spur, and ten instead of nine loculi.

The name of this species is derived from the Latin eminens ("standing high, projecting"), and refers to the development of $\mathrm{Ll}$.

Type: Holotype, an incomplete female left valve, no. 34673 .

\section{Abditoloculina fundiornata Kesling and Peterson, new species \\ Plate 1, figures 13-15}

Diagnosis: Large Abditoloculina species with each female valve having a thick lateral rim on the frill, a small simple rim around each loculus, and nine loculi.

Female: Valve elongate suboval in lateral view. Hinge line straight, anterior and posterior borders subround, and ventral border gently curved. Frill overhanging the free edge.

Trilobate; Ll a small, low lobe with a posterodorsal tip extending slightly above the hinge line, L2 and L3 knob-like, about equal in size, and L3 extending very slightly above the hinge line. Posterior part of valve only slightly convex. S1 very short and shallow; S2 sinuous, extending from hinge line to lateral rim of the frill.

Spurs adjacent to rim of the frill. Anterior spur small, subconical, directed backward. Posterior spur larger than anterior, bluntly horn-shaped, its tip directed backward.

Frill with a lateral rim, thicker in its anterior part. Ventral surface of lateral rim and partitions between the loculi ornamented with very thin, wavy longitudinal crests. Nine pear-shaped loculi, each with an extremely narrow, inconspicuous rim. Narrow submarginal ridge with very faint papillae, separated by a narrow, distinct channel from the part of the marginal surface bearing the loculi. Surface of valve granular.

Dimensions of holotype, a left valve: Length $1.16 \mathrm{~mm}$; height $0.68 \mathrm{~mm}$; width (including spurs) $0.38 \mathrm{~mm}$.

Remarks: This species most closely resembles Abditoloculina obesivelata, from which it differs in having an extremely narrow rim around each loculus instead of a rim distally enlarged to form a lunate lip.

The name of this species is derived from the Latin fundus, m. ("the bottom or base of anything"), and ornatus ("ornamented"), and refers to the wide ornamented area on the ventral side of the lateral rim of the frill.

Type: Holotype, a female left valve, no. 34668.

\author{
Abditoloculina insolita Kesling \\ Plate 1, figures 39-41, 56-59
}

Abditoloculina insolita KesLING, 1952, pp. 767-768, pl. 111, figs. 7-14.

Diagnosis: Small Abditoloculina species with each female valve having a thin distal rim on the frill, a small tubercle on the dorsal border behind L3, seven loculi, the anterior spur on the convexity of the frill marking the second loculus, and the posterior spur exceptionally long, slender, and curved.

Remarks: The frill overhangs the free edge of the valve by almost its complete width. As can be seen in anterior view, the ventral surface of the partitions between the loculi is set at about 25 degrees to the plane of the contact margin.

Illustrated specimens: Two topotypes, female left valves, nos. 34677 and 34678. Allotype, a male right valve (here re-illustrated for comparison with other Abditoloculina males), no. 27779.

Abditoloculina obesivelata Kesling and Peterson, new species

Plate 1, figures 1-3

Ctenobolbina cavimarginata ULRICH, 1900 (in part), p. 182, pl. 8, fig. 7 (not figs. 8-9). - Ellis AND MEssina, 1952 (in part), unnumbered page, fig. 7 (not figs. 8-9).

Hollina cavimarginata (Ulrich). - UlRICH AND BASSLER, 1908 (in part), p. 315, pl. 42, fig. 10 (not figs. 11-12). Grabau and Shimer, 1910 (in part), p. 357, text-fig. 1660w (not figs. 1660 w', x). - BAssLer AND KeLLETT, 1934 (in part), p. 329. - WARTHIN, 1937 (in part), card 72, fig. 7 (not figs. 8-9).

Abditoloculina cavimarginata (Ulrich). - KesLING, 1952 (in part), p. 767. - PoKorNý, 1954 (in part), text-fig. 531 (uppermost figure only).

Diagnosis: Large Abditoloculina species with each female valve having a thick lateral rim on the frill, a lunate outer lip on each loculus, and nine loculi.

Female: Valve subelliptical to subpyriform in lateral view. Hinge line straight. Anterior border round, ventral border broadly round, and posterior border subround. Anteroventral and ventral parts of free border hidden by frill.

Trilobate; L1 a low, small anterodorsal lobe with a small, inconspicuous tip extending slightly above the hinge line; L2 a large, distinct knob only a little way below the hinge line; and L3 conspicuously smaller than L2, bulbous, extending slightly above the hinge line. S1 short and narrow, separating L1 from L2; S2 sinuous, passing between L2 and L3 and between the spurs, terminating ventrally at the rim of the frill. Posterior part of the valve very gently convex, nearly flat.

Spurs distinct. Anterior spur with its base directed anteroventrally and its conical tip directed sharply backward. Posterior spur with a cylindrical base 
pointing downward and outward and a short subconical tip directed backward.

Frill with a thick lateral rim, its anterior part thick and somewhat nodular. Ventral surface of lateral rim subreticulate, with short wavy crests more or less aligned longitudinally. Nine subovate loculi, each with a surrounding rim. Rim narrow except in distal part, there enlarged to form a lunate lip. Small submarginal ridge with numerous low, inconspicuous papillae. A very low ridge extending onto the lateral surface from the rear end of the frill, becoming only an angulation and reaching nearly to the posterior corner.

Lateral surface smooth to finely granular. Anterior and posterior cardinal angles about 130 and 120 degrees.

Dimensions of holotype, a female right valve: Length $1.18 \mathrm{~mm}$; height $0.67 \mathrm{~mm}$; width (including spurs) $0.46 \mathrm{~mm}$.

Remarks: This species differs from Abditoloculina cavimarginata (Ulrich) in several ways: It has only nine instead of eleven loculi, its frill has a thick lateral rim, each loculus has a rim that is distally expanded to form a lunate lip, the spurs are smaller but more sharply pointed, and the L3 is smaller and more bulbous. However, one of the two syntypes selected for Abditoloculina cavimarginata by Ulrich (U. S. National Museum, no. 41495) belongs to this species, and we here designate it a paratype of the latter. Abditoloculina obesivelata more closely resembles Abditoloculina fundiornata, from which it differs in having a lunate outer lip at each loculus.

The name of this species is derived from the Latin obesus ("fat") and velum, n. ("frill"), and refers to the thick lateral rim on the frill.

Types: Holotype, a female right valve, no. 34665. Paratype, one of two valves on slide labeled "Cotypes, Ctenobolbina cavimarginata," U. S. National Museum, no. 41495.

\section{Abditoloculina palpebrata Kesling and Peterson, new species \\ Plate 1, figures 4-6}

Diagnosis: Large Abditoloculina species with each female valve having a thick lateral rim on the frill, a lunate outer lip on each loculus, and eight loculi.

Female: Valve suboval to subpyriform in lateral view. Hinge line straight, anterior border round, ventral border gently round, and posterior border subround. Frill overhanging the free edge.

Trilobate; Ll a low anterodorsal lobe with a small tip extending slightly above the hinge line, L2 a knob, and L3 knob-like, about the same size as L2, extending slightly above the hinge line. Posterior part of the valve very gently convex. S1 short and shallow; S2 sinuous, extending from the hinge line to the lateral rim of the frill.
Tips of both spurs broken off in holotype; bases of the spurs subconical, hollow. Posterior spur larger than anterior.

Frill with a thick lateral rim, its anterior part thicker and somewhat nodular. A very low, inconspicuous crest extending from the rear end of the frill onto the lateral surface, subparallel to the posterior border. Small subtriangular pit just behind the frill. Most of frill flat, but low, barely discernible convexities marking the positions of the last two loculi. Ventral surface of lateral rim and partitions between the loculi ornamented with fine, wavy crests more or less parallel to the free edge. Eight suboval to subquadrate loculi. The narrowest part of each partition half as wide as the adjacent loculus. Narrow rim around each loculus, distally slightly enlarged to form a lunate lip. Low submarginal ridge with numerous small papillae, separated from the part of the marginal surface bearing the loculi by a deep, narrow channel.

Surface finely granular. Anterior and posterior cardinal angles each about 115 degrees.

Dimensions of holotype, a right valve: Length $1.13 \mathrm{~mm}$; height $0.66 \mathrm{~mm}$; width (including bases of spurs) $0.40 \mathrm{~mm}$.

Remarks: This species is one of those with a thick lateral rim on the frill, like Abditoloculina obesivelata, Abditoloculina fundiornata, and Abditoloculina clavicavosa. It can readily be separated from them by its number of loculi, which is eight instead of nine or ten. The lunate outer lip on each loculus is much narrower in Abditoloculina palpebrata than in Abditoloculina obesivelata or Abditoloculina clavicavosa.

The name of this species is derived from the Latin palpebra, f. ("an eyelid"), and refers to the shape of the lunate lip distal to each loculus.

Type: Holotype, a female right valve, no. 34666.

\section{Abditoloculina prominens Kesling and Peterson, new species \\ Plate 1, figures 28-30, 48-49}

Diagnosis: Large Abditoloculina species with each female valve having an almost flat frill without a lateral rim, a large linguiform L1, a low lobate L3, nine loculi, a low node-like anterior spur, and a large, horn-shaped, pointed posterior spur.

Female: Valve subpyriform in lateral view. Hinge line straight, anterior border subround, ventral and posteroventral borders gently subround, and posterior border sharply round. Frill extending beyond the free border by less than half its width. Positions of loculi not apparent in lateral view of the frill.

Trilobate; Ll a large, linguiform lobe extending well above the hinge line, L2 a large, vertically elongate knob-like lobe, and L3 a very low, small lobe extending 
slightly above the hinge line and ventrally confluent with the lateral surface. Posterior part of the valve very gently convex, low. Sl short and shallow, separating Li and L2; S2 deep, sinuous, extending from dorsal to ventral border.

Anterior spur a low lobe ventral and slightly anterior to L2, almost the same size as L2. Posterior spur large, horn-shaped, its tip directed backward.

Frill flat, without rim of any kind. Nine subquadrate loculi. Partitions between the loculi with faint transverse grooves, their narrowest parts about half as wide as the loculi. Submarginal ridge low, with numerous small papillae, separated from the part of the marginal surface bearing the loculi by a narrow channel.

Surface finely granular, nearly smooth. Anterior and posterior cardinal angles about 115 and 130 degrees.

Dimensions of holotype, a left valve: Length $1.18 \mathrm{~mm}$; height $0.72 \mathrm{~mm}$.; width (including spurs) $0.45 \mathrm{~mm}$.

Remarks: This species is closely related to Abditoloculina eminens, from which it differs in having a deeper S2, a more pointed posterior spur, and nine instead of ten loculi.

The name of this species is derived from the Latin prominens ("jutting out"), and refers to the development of Ll.

Types: Holotype, a female left valve, no. 34674. Paratype, a female left valve, no. 34675. Unfigured paratype, a female left valve, no. 34729 .

\section{Abditoloculina pumila Kesling and Peterson, new species \\ Plate 1, figures 7-9, 16-18}

Diagnosis: Large Abditoloculina species with each female valve having an almost flat frill without a lateral rim, a small L1, a low lobate L3, and ten loculi.

Female: Valve subpyriform in lateral view. Hinge line straight, anterior and ventral borders subround, posteroventral border gently curved, and posterodorsal border round. Frill overhanging free edge by less than half its width.

Trilobate; L1 a low, small, inconspicuous swelling at the anterior corner, L2 a low, ovate knob, and L3 a low lobe projecting slightly above the hinge line. Posterior part of valve very weakly developed, only slightly convex. Sl very shallow, practically a semisulcus along the anterior edge of L2; S2 immediately anterior to midlength, rather deep, sinuous, extending from dorsal to ventral border.

Anterior spur a vertically elongate low lobe. Posterior spur massive, large, bluntly horn-shaped, curving outward and backward.

Frill from central anterior to posteroventral region, nearly flat. Ten subrectangular loculi set rather close together. Each partition with faint cross grooves, its narrowest part about one-third as wide as the adjacent loculus. Low submarginal ridge with small papillae, separated from the part of the marginal surface bearing the loculi by a narrow channel. Lateral surface finely granular.

Dimensions of holotype, a right valve: Length $1.11 \mathrm{~mm}$.; height $0.67 \mathrm{~mm}$. Width of paratype no. 34670 (including spurs) $0.44 \mathrm{~mm}$.

Remarks: This species is similar to three other species from the Jeffersonville limestone; it can easily be identified by its ten loculi, as compared with eleven in Abditoloculina cavimarginata, nine in Abditoloculina pusilla, and eight in Abditoloculina repanda.

The name of this species is derived from the Latin pumilus ("dwarfish, diminutive"), and refers to the small size and development of $\mathrm{Ll}$.

Types: Holotype, a female right valve, no. 34669. Figured paratype, a female right valve, no. 34670. Unfigured paratype, a female left valve, no. 34730 .

\section{Abditoloculina pusilla Kesling and Peterson, new species \\ Plate 1, figures 35-38}

Diagnosis: Large Abditoloculina species with each female valve having an almost flat frill without a lateral rim, a small L1, a low lobate L3, and nine loculi.

Female: Valve subelliptical to subpvriform in lateral view. Hinge line straight, anterior and ventral borders round, and posteroventral border curved. Posterior onefourth of valve unknown.

Trilobate; Ll a low, inconspicuous swelling at the anterior corner, L2 an ovate knob, and L3 a low lobe extending slightly above the hinge line. Sl a shallow groove, practically a semisulcus along the anterior edge of L2; S2 long, sinuous, very narrow between the spurs.

Anterior spur a vertically elongate lobe. Posterior spur large, its base subconical, its tip broken off and unknown.

Frill flat. Nine subrectangular loculi. Each partition between loculi more than half as wide as the adjacent loculus. Low submarginal ridge with faint papillae, separated from the part of the marginal surface with the loculi by a very narrow channel. Lateral surface smooth to finely granular.

Dimensions of holotype, an incomplete right valve: Height $0.63 \mathrm{~mm}$; width (including incomplete spur) $0.37 \mathrm{~mm}$. Estimated length about $1.00 \mathrm{~mm}$.

Remarks: Abditoloculina pusilla resembles Abditoloculina prominens in having nine loculi, a low L3, a node-like anterior spur, and a large, horn-shaped posterior spur; it can readily be distinguished by its very low $\mathrm{L}, \mathrm{l}$, which 
does not extend above the hinge line. It resembles Abditoloculina repanda, Abditoloculina pumila, and Abditoloculina cavimarginata in lateral outline, general lobation, and spurs, but can be separated from those species by the number of loculi (see Table 1).

The name of this species is derived from the Latin pusillus ("insignificant"), and refers to the development of Ll.

Type: Holotype, an incomplete female right valve, no. 34676 .

\section{Abditoloculina repanda Kesling and Peterson, new species \\ Plate 1, figures 22-24, 31-34}

Diagnosis: Large Abditoloculina species with each female valve having an almost flat frill, a small L1, a low L3, and eight loculi.

Female: Valve elongate suboval in lateral view. Hinge line straight, anterior and posterior borders subround, and ventral border evenly curved. Frill overhanging free edge by about half its width.

Trilobate; L1 very low, inconspicuous, L2 an ovate knob, and L3 small, low, extending slightly above the hinge line. Posterior part of valve low, gently convex. $\mathrm{S} 1$ a shallow groove, $\mathrm{S} 2$ long and sinuous.

Anterior spur a lobe, slightly smaller than L2. Posterior spur large, horn-shaped, directed outward and backward.

Frill flat, without rim of any kind; a low, thin ridge extending from the rear end of the frill parallel to the posteroventral border, becoming indistinct near the posterior corner. Eight subquadrate to suboval loculi, each with a low, narrow rim. Narrowest part of each partition about half as wide as the adjacent loculus. Submarginal ridge with very small, low papillae. Channel narrow. Surface smooth to finely granular.

Dimensions of holotype, a right valve: Length $1.04 \mathrm{~mm}$; height 0.60 ; width (including spurs) $0.41 \mathrm{~mm}$.

Remarks: This species has only eight loculi, whereas Abditoloculina pusilla, Abditoloculina pumila, and Abditoloculina cavimarginata, which have similar lobation, have nine, ten, and eleven loculi, respectively. Abditoloculina repanda differs from Abditoloculina palpebrata, which also has eight loculi, in lacking a lateral rim on the frill and a lunate outer lip on each loculus, and in having a low lobe-like L3 and a very low Ll.

The name of this species is derived from the Latin repandus ("bent backward"), and refers to the shape of the posterior spur.

Types: Holotype, a female right valve, no. 34672. Paratype, an incomplete female right valve, no. 34688.

\author{
Abditoloculina armata (Ulrich) \\ Plate 1, figures 68-69
}

C'tenobolbina armata UlRich, 1900, pp. 181-182, pl. 8, fig. 6. Ellis and Messina, 1952, unnumbered page, fig. 6.

Hollina armata (Ulrich). - Ulrich AND BASSLER, 1908, p. 315 , pl. 42, fig. 14. - Grabau AND Shimer, 1910, p. 357, text-fig. 1660v. - Bassler and Kellett, 1934, p. 329. SWARTZ, 1936, p. 552, pl. 80, fig. 3b. - WarThIN, 1937, card 71, fig. 6.

Abditoloculina armata (Ulrich). - KesLING, 1952, p. 767.

Diagnosis: Large Abditoloculina species with each male valve having a small $\mathrm{Ll}$ not extending above the hinge line, a knob-like L2, a bulbous L3 larger than L2, spurs compressed laterally, the anterior spur with a short conical spine along its posterior edge, the posterior spur large but not extending below the free edge, anterior branch of the velate ridge terminating on the ventral edge of the anterior spur with an enlargement, and posterior branch of the velate ridge extending from below the front spur to the posterior part of the valve.

Remarks: Swartz (1936, p. 552) has suggested that Abditoloculina armata is a dimorph of Abditoloculina cavinaarginata. We are not certain which Abditoloculina female is the dimorph of Abditoloculina armata. It seems best to maintain Abditoloculina armata as a separate species until such time as the dimorphism can be proved.

All Abditoloculina males have certain features in common, such as two velate spurs and a divided velate ridge, the anterior branch terminating on the anterior spur and the posterior branch extending from below the anterior spur to the posteroventral or posterior region. They vary in the lobation, the shape of the spurs, and the nature of the rear terminus of the anterior branch of the velate ridge. The posterior spurs of Abditoloculina armata and several unnamed males are compared in Table 2. We do not have enough specimens to determine whether or not the differences noted among these males are significant.

Illustrated specimen: Topotype, a male right valve, no. 34652 .

\section{Unnamed Abditoloculina males}

Several males of this genus were found which differ from Abditoloculina armata. They are grouped into four types, here called simply A, B, C, and D. The females to which they should be assigned are not known. Additional specimens should be studied before specific assignments are attempted.

The males of many hollinid ostracods can be readily determined to be dimorphs of a particular species for which the female is known, by the similarities in general shape of valve, lobation, and ornamentation between males and females. In this case, the solution is complicated by the close affinities of females of different species. The females of Abditoloculina fundiornata, Abditoloculina clavicavosa, Abditoloculina obesivelata, and 
Abditoloculina palpebrata, for example, have very similar lobation. Their outstanding differences are in the loculi and frill, dimorphic structures which are not present in the male.

TABLE 2

COMPARISON OF POSTERIOR SPURS IN MALE VALVES OF Abditoloculina FROM THE

JEFFERSONVILLE LIMESTONE

\begin{tabular}{c|c|c}
\hline Shape of spur & $\begin{array}{c}\text { Spur extending } \\
\text { below free edge }\end{array}$ & $\begin{array}{c}\text { Spur terminating } \\
\text { above free edge }\end{array}$ \\
\hline \hline $\begin{array}{c}\text { Base bulbous, tip } \\
\text { with tubercle }\end{array}$ & & Type B \\
\hline $\begin{array}{c}\text { Subconical or } \\
\text { horn-shaped, } \\
\text { not compressed }\end{array}$ & Type C & Type A \\
\hline $\begin{array}{c}\text { Broad, laterally } \\
\text { compressed }\end{array}$ & Type D & A. armata \\
\hline
\end{tabular}

In addition, the males are in several stages of development, or instars. It is difficult, in a small collection, to decide which specimens are adult and can therefore be compared directly with the females. It would seem, on the basis of the illustrated specimens, that lobation changes considerably during ontogeny. Many specimens of each species would be required to work out the ontogenetic series satisfactorily.

Type $A$ (pl. 1, figs. 50-51): Only one specimen of this type was discovered. Valve elongate elliptical. Hinge line straight, anterior and posterior borders subround, and ventral border gently curved. $\mathrm{Ll}$ a low lobe with a posterodorsal small tubercle projecting above the hinge line, L2 a knob, and L3 knob-like and about the same size as L2. A small node anteroventral to L1 but behind the anterior border. S1 short, narrow; S2 deep, sinuous. Anterior spur somewhat compressed. Posterior spur horn-shaped, its apex pointing more outward than backward.

This type resembles type $\mathrm{B}$, but has a more conical than bulbous posterior spur, L3 about the same size as L2 instead of smaller, and the tubercle on the rear edge of the anterior spur small instead of large and conspicuous. The illustrated specimen is an immature(?) left valve, no. 34681 (length $0.86 \mathrm{~mm}$; height $0.47 \mathrm{~mm}$; width $0.34 \mathrm{~mm}$.$) .$

Type $B$ (pl. 1, figs. 52-55): Similar to type A. Ll low, without a posterodorsal tubercle, its dorsal border slightly above the hinge line and round; L2 an ovate knob; L3 smaller than L2, round, relatively low. A small lobe below and anterior to $\mathrm{Ll}$, about the same size as Ll. Spurs with bulbous bases. Anterior spur with a prominent tubercle on its rear border. Posterior spur with a conspicuous, posteriorly directed tubercle. This type is distinguished from others by its bulbous spurs. The illustrated specimens are a left valve, no. 34682 (length $0.91 \mathrm{~mm}$.; height $0.47 \mathrm{~mm}$.; width $0.28 \mathrm{~mm}$.), and an incomplete right valve, no. 34683 .
Type C (pl. 1, figs. 62-63, 66-67): The larger valve found is subelliptical to subpyriform in lateral view. $\mathrm{Ll}$ a lobe with a conspicuous tubercle extending above the hinge line, L2 a vertically elongate knob, and L3 large, bulbous, extending above the hinge line. Node anteroventral to Ll located behind the anterior border. Spurs large. Anterior spur with a tubercle on its rear edge and a ventral projection marking the rear terminus of the anterior branch of the velate ridge. Posterior spur horn-shaped, strongly curved in both lateral and ventral views. The smaller specimen has L3 much smaller than L2, and the posterior spur terminating just above the free edge, but agrees with the larger specimen in other features.

This type differs from Abditoloculina armata and from type $A$ and type $B$ in having the posterior spur extending below the free edge. Its posterior spur is nearly round in cross section, and the node below $\mathrm{Ll}$ is behind the anterior border, in contrast to type $\mathrm{D}$, in which the posterior spur is laterally compressed and the node below L1 projects forward. The illustrated specimens are a large right valve, no. 34684 (length $1.03 \mathrm{~mm}$; height, including spurs, $0.61 \mathrm{~mm}$.; width $0.42 \mathrm{~mm}$.), and a small right valve, no. 34685 (length $0.94 \mathrm{~mm}$.).

Type D (pl. 1, figs. 60-61, 64-65): Similar to type C except that the node below $\mathrm{Ll}$ projects forward and extends beyond the rest of the anterior border, the spurs are compressed, the anterior spur projects farther laterally, and the posterior spur is wider and less curved. The smaller specimen has L3 about the same size as L2, and its posterior spur does not extend below the free edge. The illustrated specimens are a large right valve, no. 34686 (length $1.06 \mathrm{~mm}$; height $0.61 \mathrm{~mm}$; width $0.41 \mathrm{~mm}$.), and a small right valve, no. 34687 (length $0.96 \mathrm{~mm}$.).

\section{Genus Adelphobolbina Stover, 1956}

Type species: Ctenobolbina papillosa Ulrich, 1891, p. 186, pl. 15, fig. 8a-c, by designation of Stover, 1956, p. 1103.

Diagnosis: Hollinid genus with each valve essentially bilobate, having a large L1 and a very large L3 joined to a ventral lobe to form an exceptionally well developed U-shaped ridge around the deep S2; L2 partly distinguishable in some species, but invariably joined to $\mathrm{Ll}$; typically strongly papillose on the lobes and the posterior part of the valve; prominent, long frill in both dimorphs, separated from the marginal or submarginal ridge by a wide channel; female with a slightly incurved frill, in many species little different from the flat or slightly flared frill of the male.

\section{Adelphobolbina papillosa (Ulrich) Plate 2, figures 25-30}

Ctenobolbina papillosa UlRiCH, 1891, p. 186, pl. 15, fig. 8a-c. RAYMOND, 1904, p. 174. - U'lRICH AND BASSLER, 1908, p. 310 , pl. 40, figs. 21-22. - BAssler and Kellett, 1934, p. 254. - Coryell and Malkin, 1936, p. 3, text-fig. 8. - 
Swartz, 1936, pl. 80, fig. 1f-g. - Warthin, 1937, card 68, fig. 8a-c. - Ellis AND MEssina, 1952, unnumbered page, fig. 8a-c. - KESLING AND TABOR, 1953, p. 88, pl. 3, figs. 16-17.

?Ctenobolbina papillosa Ulrich. - WARTHIN, 1937, card 68, fig. A. Adelphobolbina papillosa (Ulrich). - Stover, 1956, pp. 1103 1104.

Diagnosis: Adelphobolbina species with each valve having numerous large, spine-like papillae and very small, inconspicuous papillae on all of the lateral surface except the frill and the deep part of S2, frill wide and smooth, and L2 completely fused with L1.

Illustrated specimens: Topotypes, two male right valves, nos. 28093 and 34653, and a male left valve, no. 34651.

\section{Genus Ctenoloculina Bassler, 1941}

Type species: Tetradella cicatricosa Warthin, 1934, p. 209, pl. 1, figs. 4-6, by designation of Bassler, 1941, pp. 22-23.

Diagnosis: Hollinid genus with each valve distinctly quadrilobate, having a D-shaped L4 and vertical ridges for L1, L2, and L3; sulci deep; lobes ornate in known species; each male with velate spurs on the first three lobes; each female with six loculi and no spurs.

\section{Ctenoloculina exocha Kesling and Perterson, new species \\ Plate 2, figures 8-13, 17-19}

Diagnosis: Ctenoloculina species with each valve having the first three lobes projecting well above the hinge line and terminating with sharply pointed, posteriorly directed tips, set at an angle of about 80 degrees to the hinge line, and wider than the sulci, all lobes ornamented with low papillae and surrounded by narrow rims, and L4D-shaped and twice as wide as L2, extending above the hinge line; male with ventral spurs on L1, L2, and L3, the spur on L1 pointing forward, on L2 pointing downward, and on L3 pointing backward, L1 concave anteriorly; female with a wide frill, overhanging the free edge by most of its width, confluent with L1, L2, and L3, and ornamented with slightly smaller papillae than the lobes, six round loculi each with a rim distally expanded as a lunate lip, and S1 and S2 ventrally wide, truncated by the frill and bearing two convexities marking the positions of the second and fourth loculi.

Male: Valve subelliptical in lateral view. Hinge line straight, anterior border round, ventral border gently curved, and posterior border curved.

Quadrilobate; L1, L2, and L3 slightly wider than sulci, nearly vertical, dorsally extending well above the hinge line, with sharply pointed, posteriorly directed tips, ventrally projecting below the free edge as spurs; L4 subrectangular to D-shaped, twice as broad as L2 or L3, projecting slightly but distinctly above the hinge line. All lobes ornamented with closely spaced small papillae and bounded on all sides by small rims. Ll the smallest of the four lobes, crescent-shaped, concave anteriorly, its spur extending forward beyond the anteroventral part of the free edge. L2 nearly straight, forming an angle of about 80 degrees with the dorsal border. L3 long, parallel to L2, slightly constricted in its middle, its spur directed posteroventrally. All sulci deep, with nearly vertical sides, extending from the dorsal to the ventral border; average width of each sulcus slightly less than that of L2 or L3.

Anterior and posterior cardinal angles about 95 degrees each. Sulci and marginal surface smooth. Row of small, discrete submarginal papillae midway between the spurs and the free edge.

Dimensions of holotype, a left valve: Length $1.03 \mathrm{~mm}$; height $0.59 \mathrm{~mm}$; width $0.21 \mathrm{~mm}$.

Female: Lobation similar to that of male except for frill. Frill from anteroventral end of $\mathrm{Ll}$ to pointed terminus behind S3, strongly convex anteriorly below its confluence with $\mathrm{Ll}$, with rim and ornamentation similar to those of the lobes but somewhat smaller, strongly overhanging the free edge by almost its full width. S1 and S 2 with semicircular ventral ends next to the frill. Each sulcus with a low round node in its ventral part, that of S1 marking the second loculus, that of S2 the fourth loculus, and that of S3 the sixth and last loculus. Six round loculi, overhung by the frill, each surrounded by a rim, very narrow except in its thickened, lunate, lip-like distal part. Rims of adjacent loculi tangent.

Dimensions of allotype, a left valve: Length $1.07 \mathrm{~mm}$; height 0.76 ; width $0.21 \mathrm{~mm}$.; length exclusive of frill $0.97 \mathrm{~mm}$; height exclusive of lobes and frill $0.51 \mathrm{~mm}$.

Remarks: This species is similar to Ctenoloculina elongata Stewart (1950, pp. 659-660, pl. 85, figs. 22-23) in having the lobes pointed and projecting well above the hinge line, but differs in having narrower sulci and wider lobes.

The name of this species is derived from the Greek $\varepsilon$ ko\%os ("projecting, lofty"), and refers to the dorsal projections of L1, L2, and L3 above the hinge line.

Types: Holotype, a male left valve, no. 34644. Allotype, a female left valve, no. 34645. Paratypes, two female right valves, nos. 34646 and 34647 .

\section{Ctenoloculina platyca Kesling and Peterson, new species \\ Plate 2, figures 14-16, 20-22}

Diagnosis: Ctenoloculina species with each female valve having low, broad L1, L2, and L3, each about twice as wide as the sulci, ventrally confluent with the narrow frill, and dorsally round, with only Ll and L3 extending slightly above the hinge line; Sl straight, ventrally widened and truncate at the frill, S2 crooked, rather S-shaped, and S3 L-shaped, narrow and vertical through most of its length but with a sharp angle and posterior deflection against the rear part of the frill; 
L4 slightly wider than L3, D-shaped; six round loculi, each with a narrow rim; exteriors of second, fourth, and sixth loculi forming small convexities in the lower parts of S1, S2, and S3, respectively.

Female: Valve subelliptical in lateral view. Hinge line straight, anterior and posterior borders subround, and ventral border curved.

Quadrilobate, with broad, low lobes. L1, L2, and L3 each about twice as wide as the adjacent sulcus, ventrally confluent with the frill, and dorsally round; Ll straight, set at about 70 degrees to the hinge line, slightly constricted at its junction with the frill; L2 widest in its dorsal half, with a straight anterior edge at about 83 degrees to the hinge line, and a sinuous posterior edge, terminating dorsally slightly below and nearly tangent to the hinge line; L3 panduriform, constricted in its middle and at its junction with the frill, dorsally extending slightly above the hinge line. L4 D-shaped, a little wider than L3, dorsally extending very slightly above the hinge line. S1 narrow, straight, except ventrally wider and truncate at the frill; S2 crooked, S-shaped but with angular geniculations, ventrally wide and bluntly truncate at the frill; S3 long, narrow, and vertical, except at its ventral end, where it is slightly expanded and turned backward along the rear part of the frill.

Frill narrower than Ll, arcuate, extending from its confluence with $\mathrm{Ll}$ to its posterior pointed terminus slightly posterior to $\mathrm{S} 3$, overhanging the free edge by only about half its width. Six round, equal loculi, each with a narrow rim; rims of adjacent loculi tangent. Center of posterior (sixth) loculus aligned with the posterior edge of L3, half the loculus being below L3 and the other half below S3. Low convexities formed in the lower parts of S1, S2, and S3 by the exteriors of the second, fourth, and sixth loculi, respectively.

Dimensions of holotype, a left valve: Length $0.99 \mathrm{~mm}$; height $0.63 \mathrm{~mm}$.; width $0.21 \mathrm{~mm}$.

Remarks: No males of this species have been found. Ctenoloculina platyca closely resembles Ctenoloculina cicatricosa (Warthin, 1934, p. 209, pl. 1, figs. 4-6), but has wider lobes and narrower sulci. Ctenoloculina platyca has lobes twice the width of sulci, whereas Ctenoloculina cicatricosa has lobes and sulci of about equal width. In addition, the angle formed by the hinge line and L2 in the left valve is about 83 degrees in Ctenoloculina platyca and about 75 degrees in Ctenoloculina cicatricosa, the posterior loculus is slightly more posterior in Ctenoloculina platyca, and the lobes are somewhat lower in Ctenoloculina platyca.

The name of this species is derived from the Greek iix-u»ss ("wide, broad"), and refers to the form of the lobes.

Types: Holotype, a female left valve, no. 34648. Paratype, another female left valve, no. 34649 .

\section{Genus Flaccivelum Kesling and Peterson, new genus}

Type species: Winchellatia teleutaea Kesling and Tabor, 1952, p. 762, pl. 111, figs. 20-23, here designated.

Diagnosis: Hollinid genus with each valve trilobate but having L2 inconspicuous and partly fused with L1; S2 very long, sinuous; velate structure in female a broad incurved frill developed as a ventral continuation of the lateral surface; in male, a small velate ridge along the bend between the lateral and marginal surfaces.

Description: Each valve subpyriform in lateral view. L1 wide, low, confluent with ventral lobe. L2 vertically elongate, confluent with ventral lobe and, in some species, nearly confluent with Ll. L3 a lobe extending above the hinge line, separated from the ventral lobe by a broad, very shallow depression only. Posterior part of the valve gently convex, not lobate. Sl shallow, scarcely developed in some species. S2 long, sinuous, conspicuous, extending from the hinge line to or nearly to the ventral border, broad and shallow in its ventral half. A posteroventral projection of the ventral lobe.

Male with a sharp bend between the lateral and marginal surfaces, with a small velate ridge or crest along the bend, beginning at the anterior corner and terminating at the tip of the posteroventral projection of the ventral lobe.

Female with a broad incurved frill, perfectly confluent with the rest of the lateral surface, edged by a narrow crest from the anterior corner to the posteroventral projection of the ventral lobe.

Remarks: In addition to Flaccivelum informis (Ulrich), described below, this genus includes Flaccivelum teleutaeum (Kesling and Tabor, 1952, p. 762, pl. 111, figs. 20-23), Flaccivelum deminutum (Kesling and Tabor, 1953, pp. 91-92, pl. 2, figs. 20-23), and Flaccivelum deliquiatum (Kesling and Tabor, 1953, pp. 90-91, pl. 2, figs. 24-29), all three of which were originally assigned to the genus Winchellatia. Winchellatia is a genus of Ordovician dimorphic ostracods described by Kay (1940, pp. 253254), having L 3 tangent to the hinge line but not projecting above it, and the velate structure in both dimorphs passing below the posteroventral projection of the ventral lobe instead of onto it. As suggested by Jaanusson (1957, p. 410), the greater development of L3 in the Devonian species distinguishes them from the Ordovician species that have been assigned to Winchellatia. Jaanusson assigns Winchellatia to the family Sigmoopsidae (1957, p. 378).

The name of this genus is derived from the Latin flaccus ("flaccid, flabby") and velum, n. ("frill"), and refers to the form of the frill in the female, which hangs downward from the lateral surface without any line of demarcation.

\section{Flaccivelum informis (Ulrich) Plate 2, figures $1-7$}

Ctenobolbina informis UlRich, 1891, p. 187, pl. 15, fig. 6a-c. Ellis and Messina, 1952, unnumbered page, fig. 6a-c. 
Hollina informis (Ulrich). - UlRICH AND BASSLER, 1908, p. 315. Bassler and Kellett, 1934, p. 330. - Warthin, 1937, card 75, fig. 6a-c.

Diagnosis: Flaccivelum species with each valve having $\mathrm{L} 2$ partly fused to $\mathrm{Ll}$, the dorsal edge of $\mathrm{Ll}$ round and extending above the hinge line, and the ventral half of S2 only a very shallow groove; as seen in ventral view, the frill of the female and the velate ridge of the male encroaching onto the posteroventral projection of the ventral lobe in an even, sweeping curve.

Male: Valve subpyriform in lateral view. Hinge line straight, anterior border round with radius little more than half the height, ventral border gently convex, and posterior border subround with radius nearly equal to the height. Posterior cardinal angle about 90 degrees.

Ll wide, low, dorsally round, extending above the hinge line, ventrally confluent with the anterior part of the ventral lobe. L2 an elongate lobe, partly joined to L1 and the ventral lobe. L3 lobate, extending above the hinge line, separated from the posterior part of the ventral lobe by a shallow, broad, inconspicuous groove. Posterior part of valve low, gently convex. Ventral lobe large, separated into two parts by the very shallow ventral half of S2. S1 narrow, shallow, confluent with S2 around the dorsal end of L2. S2 long and sinuous, deep and well defined in its dorsal half, shallow and inconspicuous in its ventral half. A prominent posteroventral projection of the ventral lobe, confluent with the rest of the lateral surface but forming an angular, pointed process directed backward.

Velate structure a very low ridge, practically a crest, along the sharp bend between the lateral and marginal surfaces, extending from the anterior corner to the posteroventral projection. As seen in anterior view, the dorsal two-thirds of the velate ridge are straight and parallel to the free edge, and the ventral one-third is set at a 45-degree angle away from the free edge. In ventral view, velate ridge curving evenly onto the posteroventral projection. A row of small submarginal papillae and a few irregularly scattered papillae of similar size immediately distal to it. Lateral surface smooth.

Dimensions of topotype no. 34641, a right valve: Length $1.24 \mathrm{~mm}$.; height $0.71 \mathrm{~mm}$.; width $0.36 \mathrm{~mm}$.

Female: Frill strongly curved inward, confluent with the lateral surface, distally bearing a small crest. As seen in anterior view, the dorsal one-third of the frill is close to the free edge and parallel to it, the frill curving thence sharply outward; the ventral two-thirds of the frill are vertical, parallel to the dorsal one-third but distal from it. As seen in ventral view, the posterior part of the frill is curved outward onto the posteroventral projection. Submarginal papillae and a few adjacent papillae as in the male.

Dimensions of topotype no. 34642, a left valve: Length $1.38 \mathrm{~mm}$.; height $0.91 \mathrm{~mm}$.; width $0.38 \mathrm{~mm}$.
Remarks: Although the holotype, U. S. National Museum, no. 41320, is worn and incomplete, we feel confident that it is conspecific with the specimens described and illustrated in this paper. This species closely resembles Flaccivelum teleutaeum (Kesling and Tabor), from which it differs in having Ll more lobate and extending above the hinge line, a smaller and more distinct L3, and the velate structure curving evenly onto the posteroventral projection in each dimorph instead of curving abruptly outward and recurving to form an "S."

Illustrated specimens: Topotypes, a male right valve, no. 34641 ; a male left valve, no. 34643; and a female left valve, no. 34642 .

\section{Genus Hollina Ulrich and Bassler, 1908}

Type species: Ctenobolbina insolens Ulrich, 1900, pp. 182183, pl. 8, figs. 10-11, by designation of Ulrich and Bassler, 1908, p. 315.

Diagnosis: Hollinid genus with each valve quadrilobate, having a lobe-like L1, a node-like L2, a bulbous L3, and a node- or lobe-like L4, all strongly developed; L3 partly joined to some form of ventral lobe in known species; male with two prominent spurs, each joined to some form of ventral lobe; female with a prominent frill, so strongly incurved that its distal edge lies in the plane of the contact margin.

\section{Hollina insolens (Ulrich) Plate 2, figures 31-35}

Ctenobolbina insolens ULRICH, 1900, pp. 182-183, pl. 8, figs. 10-11. - Ellis ANd Messina, 1952, unnumbered page, figs. 10-11.

Hollina insolens (Ulrich). - UlRICH AND BASSLER, 1908, p. 315, pl. 42, figs. 8-9. - Grabau AND Shimer, 1910, p. 357, text-figs. 16631, m. - Ulriah AND BAsSLER, 1923, textfig. 20, no. 9. - Kellett, 1929, pp. 199-200. - Moore, 1929, p. 100. - BAssLer AND Kellett, 1934, pp. 29, 330, text-fig. 11, no. 9. - WARThin, 1937, card 76, figs. 10-11. SHIMER AND SHrock, 1944, p. 671, pl. 282, figs. 11-12. Kesling, 1951, pl. 2, fig. 7. - Kesling, 1952, p. 765, pl. 111, figs. 1-6. - PoKorný, 1954, text-fig. 530.

Diagnosis: Hollina species with each male valve thick, having a large vertically elongate lobe for L1, a small node-like knob for L2, a large bulb for L3, a vertically elongate knob for L4, a long sinuous S2 deeper in its dorsal half but extending to the ventral border, a very large ventral ridge partly joined to L3 and curving downward and forward to the bluntly round posterior spur, and a small ventral lobe partly joined to $\mathrm{Ll}$ and tapering downward and slightly backward to the small round tip of the anterior spur; female valve having the frill joined to $\mathrm{Ll}$, the ventral lobe, and the ventral ridge, an anteroventral cavity bounded by the frill, $\mathrm{Ll}$, and the ventral lobe and S2 terminated by the frill; all valves having closely spaced papillae on the lobes and large discrete submarginal papillae. 
Illustrated specimens: Topotypes, a male left valve, no. 34654, and an incomplete female right valve, no. 34655 . Allotype, a male right valve, no. 27776.

\section{Hollina compressa Kesling and Peterson, new species Plate 2, figures $36-38$}

Diagnosis: Hollina species with each valve thin and rather flat, having a wide, flat ventral lobe confluent with all lobes; the male with a wide, flat anterior spur partly confluent with the ventral lobe; female with a wide frill joined to $\mathrm{Ll}$ at its anterior end, to the ventral lobe at its middle and posterior inner edges, and with two deep cavities between the frill and the ventral lobe, one below $\mathrm{L} 1$ and the other below $\mathrm{S} 2$.

Male: Valve compressed, subpyriform in lateral view. Hinge line straight, anterior and posterior borders round, and ventral border gently curved except for convex projections of spurs.

Quadrilobate, with all lobes joined to a flat, long ventral lobe; L1 a flat lobe, L2 a flat node anteroventrally joined to the ventral lobe, L3 a laterally compressed bulb, and L4 a flat lobe. S1 and S2 dorsally confluent above L2; S1 very short, deep, directed anteroventrally; S2 deep, narrow and sloping posteroventrally in its dorsal half, with posterior and anteroventral extensions in its ventral half, giving it the shape of a short, inverted $\mathrm{T}$, terminating at about the middle of the valve; S3 short, deep, curved, separating L3 and L4. A narrow, flat strip of valve along the posteroventral border and below the ventral lobe.

Anterior spur elliptical, elongate parallel to the anteroventral border, relatively flat and thin, joined to the ventral lobe only along part of its dorsal border, its anterodorsal edge bounded by a pit and its posterodorsal edge by a conspicuous groove; this spur more closely resembling a short frill than a spur, without a tip but with a round posteroventral end. Posterior spur broken from the holotype and paratype, the broken edge in the holotype showing a hollow, longitudinal slot (pl. 2, fig. 37); presumably, the posterior spur resembling the anterior, but unconfirmed. Surface finely papillose; where surface layer broken away, the inner layer showing somewhat coarser papillae; outer layer having a pebbly texture.

Dimensions of holotype, a right valve: Length $1.12 \mathrm{~mm}$.; height $0.71 \mathrm{~mm}$.; width $0.27 \mathrm{~mm}$.

Female: Lobation like that of male. Frill extending from anterior corner to posteroventral part of valve, strongly incurved, its distal edge lying in the plane of the contact margin and the hinge. Frill confluent with ventral Jobe anterodorsally, anteroventrally, and posteroventrally, but separated from it anteriorly by a deep, small, subtriangular pit and ventrally by a subquadrate deep pit.

Remarks: The allotype and only female valve was whole when found, but was firmly cemented to a bryozoan and nearly concealed by an overlying fragment of another bryozoan. It was possible, by tilting the mass at a steep angle, to see most of the surface of the valve. As frequently happens with silicified specimens, and (seemingly) very frequently with those of new species, the female valve could be studied thoroughly and photographed only if the overlying material was removed, with the risk of damaging the specimen. It broke into many pieces. Several of the pieces were recovered and glued together in as nearly their proper places as could be determined. The result ( $\mathrm{pl}$. 2, fig. 38) is not very good, but it is the only female valve we have. The description is therefore based partly on what we remember the specimen originally to have been, rather than on what it is now.

This species can be compared with Hollina insolens, but it differs from that species in several features: It has a long ventral lobe extending nearly the full length of the valve and joined to $\mathrm{L} 1, \mathrm{~L} 2$, and $\mathrm{L} 4$, all sulci limited to the dorsal half of the valve, and the valve very compressed. The spurs of the male, although hollow, are much thinner than those of any other species of Hollina known, and are of different shape.

The name of this species is derived from the Latin compressus ("compressed"), and refers to the form of the valve.

Types: Holotype, a male right valve, no. 34656. Allotype, a female right valve, incomplete and broken into several pieces, no. 34657. Unfigured paratype, an incomplete male left valve, no. 34717.

\section{Genus Hollinella Coryell, 1928}

Type species: Hollinella dentata Coryell, 1928, pp. 377-378, by original designation.

Diagnosis: Hollinid genus with each valve trilobate, having a lobe-like L1, a node-like L2, a bulbous L3, some kind of ventral lobe or lnbes, and a low posterior part of the valve; $\mathrm{S} 1$ weakly developed, and $\mathrm{L} 2$ in some species joined to $\mathrm{Ll}$ (but retaining its identity), $\mathrm{S} 2$ much deeper, ventrally extending to the middle of the valve; dimorphism difficult to detect in some species, consisting of slight variation in curvature of the frill; the frill of the female more incurved than that of the male.

\section{Hollinella antespinosa (Ulrich) Plate 2, figures 39-42}

Ctenobolbina? antespinosa UlRICH, 1891, p. 187, pl. 15, fig. 9a-c. Ellis and Messina, 1952, unnumbered page, fig. 9a-c. Hollina antespinosa (Ulrich). - UlRICH AND BASSLER, 1908, p. 315. Hollina antispinosa [sic] (Ulrich). - Grabau ANd Shimer, 1910, p. 357 , text-fig. $1660 \mathrm{y}, \mathrm{y}^{\prime}, \mathrm{y}^{\prime \prime}$.

Hollinella antespinosa (Ulrich). - Kellett, 1929, p. 200. Bassler and Kellett, 1934, p. 331.

Hollina hamiltonensis (Jones).-WARTHI.s, 1937, card 74, fig. 9a-c. ?Hollinella plauta KesLING AND TABOR, 1953, pp. 86-87, pl. 1, figs. 18-22.

Diagnosis: Hollinella species with each valve large, elongate subelliptical, ornamented with small, closely 
spaced papillae and scattered larger papillae on the lateral surface; Ll broad and low, L2 vertically elongate and nearly joined to $\mathrm{Ll}$ along its anterior edge, being separated by a very shallow groove, L3 bulbous with a dorsal tubercle projecting above the hinge line, Sl short and shallow, S2 deep, with a sloping anteroventral extension below L2 and a rear extension under the anteroventral part of L3, a shallow groove along the posterior edge of $\mathrm{L} 3$, and a long ventral lobe from $\mathrm{Ll}$ and L2 to the posterior part of the valve, narrow and ridge-like below S2 and its extensions; frill well developed, smooth, extending from anterior corner to posteroventral region, its rear terminus thickened and spine-like.

Remarks: The holotype, U. S. National Museum, no. 41319, is somewhat worn and damaged in its anterior region, but appears to be conspecific with the specimens illustrated here. On the other hand, we seriously doubt that the specimens from the Genshaw formation of Michigan described as Hollinella plauta by Kesling and Tabor are conspecific with those from the Jeffersonville formation, but because we are uncertain, we list Hollinella plauta as a questioned synonym of Hollinella antespinosa. We note that, although the lobation and ornamentation are very similar, the ostracods from the Genshaw are rather smaller $(1.44 \mathrm{~mm}$. long, as compared with $1.60 \mathrm{~mm}$. in a specimen from the Jeffersonville), the anteroventral extension of S2 below L2 is not as deep or long, the large papillae are not as high, and the frill is attached to the valve farther from the free edge. Additional specimens from both formations must be found and compared in order to determine whether or not these minor differences are specific.

Illustrated specimens: Topotypes, two right valves, nos. 34658 and 34659.

\section{Hollinella kolmodini (Jones) \\ Plate 2, figures 45, 48-49}

Beyrichia kolmodini Jones, 1890, p. 538, pl. 20, fig. 6. - RAYmOND, 1904, p. 174. - Ellis AND MESSINA, 1954, unnumbered page, fig. 6 .

Beyrichia (?Depranella) kalmodini [sic] Jones. - ULRICH, 1891, p. 190, pl. 14, fig. 1a-c.

Hollina kolmodini (Jones). - Ulrich AND BAsSLer, 1908, p. 315, pl. 42, figs. 5-7. - Grabau And Shimer, 1910, p. 358, text-fig. 1665f-h. - MOORE, 1929, p. 100.

Hollinella kolmodini (Jones). - Bassler ANd Kellett, 1934, p. 333. - WARTHIN, 1937, card 78, figs. la-c, 6. - SHIMER AND SHrock, 1944, p. 669, pl. 282, figs. 1-3. - Not Kesling and McMillan, 1951, p. 55, pl. 1, fig. 10.

Diagnosis: Hollinella species with each valve subovate, $\mathrm{L} 1$ and the anteroventral edge of L2 joined to a long prominent ventral lobe, L3 bulbous and ventrally truncate by a deep narrow groove separating it from the ventral lobe, Sl narrow, curved around the anterior border of L2, and S2 deep, curved around the posterior and ventral borders of L2, nearly reaching the ventral end of S1, dorsally confluent with $\mathrm{Sl}$; surface finely granulose, with several large, shallow punctae on the lobes; frill thick, slightly convex, extending from corner to corner.

Remarks: The specimen from the Bell shale assigned to this species by Kesling and McMillan (1951, p. 55) is similar in lobation, but differs in having the frill terminated in the posteroventral region, $\mathrm{S} 1$ and S2 joined below L2, L3 spherical instead of ventrally truncate, and the lateral surface without scattered punctae. We do not believe it should be retained in Hollinella kolmodini.

Illustrated specimens: Topotypes, a right and a left valve, nos. 34663 and 34664.

\section{Hollinella spiculosa (Ulrich)}

Ctenobolbina spiculosa Ulrich, 1900, p. 181, pl. 8, fig. 5. Ellis and Messina, 1952, unnumbered page, fig. 5.

Hollina spiculosa (Ulrich). - Ulrich AND BAsSler, 1908, p. 315, pl. 42, fig. 13. - Grabau AND Shimer, 1910, p. 357, text-fig. 1660u. - BAsSler and Kellett, 1934, p. 330. - SWARtz, 1936, pl. 80, fig. 3d. - Warthin, 1937, card 77, fig. 5. - Kesling, 1951, pl. 3, fig. 7.

Diagnosis: Hollinella species with each valve conspicuous by its ornamentation of small, closely spaced sharp granules and scattered long, sharp spines; Ll terminating well above the hinge line as a spine; frill very wide, convex but not strongly incurved, projecting above the hinge line at its pointed anterodorsal tip and extending to the posteroventral region, not spinose like the lateral surface.

Remarks: No specimens of this unusual species were found in the present collection. Our knowledge of the species continues to be based on the holotype. In our opinion, the lack of an L4 and the lack of strong incurvature of the frill exclude this species from Hollina; certainly, the lobation differs markedly from that in other species now assigned to Hollina. The male of this species is unknown. When a male is found, the nature of the dimorphism will probably show to what genus it belongs.

Hollinella strumosa Kesling and Peterson, new species Plate 2, figures $43-44,46-47,50-51$

Diagnosis: Hollinella species with each female valve having a very long, vertical, ridge-like $\mathrm{Ll}$, a vertically elongate node for L2, a bulbous, very large L3 extending well above the hinge line, a slanting bulbous ventral lobe from below L2 to its acuminate end below L3, and a knob in the posteroventral region bearing a posterior large tubercle; S1 and S2 joined above and below L2, extending to the frill along the rear edge of $\mathrm{Ll}$; frill narrow, from the anterior corner to the posteroventral region, terminating below the edge of the posteroventral knob; surface smooth to finely granulose except the nearly flat posterior part of the valve, there bearing large scattered papillae. 
Female: Valve elongate subovate in lateral view. Hinge line straight, anterior border round, ventral and posteroventral borders gently curved, and posterior border curved. Posterior end of valve rather blunt in the holotype, convex in the paratype.

Ll long, vertical, ridge-like, dorsally round and extending above the hinge line, somewhat wider in its ventral half. L2 a prominent, vertically elongate node completely isolated by sulci. L3 exceptionally large and bulbous, dorsally spherical, ventrally truncate. Posterior part of valve convex. Ventral lobe very bulbous, subpyriform, slanting, its larger end lying below L2 and its acuminate end below L3. Posteroventral knob in the posteroventral region, tangent to the border, situated below the rear half of L3, bearing a large, prominent tubercle on its posterodistal surface. Sl long, deep, narrow, extending from the hinge line to the frill along the rear side of L1. S2 deep, confluent with S1 above and below L2, joined to a deep, narrow groove separating $\mathrm{L} 3$ from the ventral lobe.

Frill narrow, thick, tapering distally, its junction with the rest of the valve smooth and not marked in any way, extending parallel to the free edge from the anterior corner to the posteroventral region, there terminating proximal to the posteroventral knob. A row of distinct marginal (left valve) or submarginal (right valve) papillae. Lateral surface smooth to finely granular, except for scattered large papillae on the posterior part of the valve.

Dimensions of holotype, a left valve: Length $1.41 \mathrm{~mm}$.; height $0.89 \mathrm{~mm}$; width $0.43 \mathrm{~mm}$.

Male: One incomplete left valve was found that differed from the female valves. It shows signs of slight abrasion and wear, but we believe it shows the characters of the male, although perhaps somewhat modified.

Hinge line straight, anterior border round, and ventral border gently curved, as in the female. Posterior part of valve broken off and unknown. Lobes like those of the female. No velate structure whatever, except possibly the acutely rounded bend between the lateral and marginal surfaces.

Remarks: The genus Hollinella has been utilized by micropaleontologists for hollinid ostracods with many kinds of lobation and velate structures. Some species have frills from corner to corner (for example, Hollinella kolmodini, described and illustrated here), whereas most have the frill restricted to the anterior and ventral borders. Until now, no species has been described in which one dimorph has no velate structure; unless we regard the round edge of the bend as velate, the male of Hollinella strumosa described above shows no velate structure. We wish to point out that this specimen shows some signs of abrasion, although not to a great degree; it does not seem likely that the specimen originally had even a ridge as a velate structure. If additional male specimens are found which show the same features as those present in this one, the dimorphism and lobation can be considered sufficiently different from those of other ostracods assigned to Hollinella to make this form a new genus.

The name of this species is derived from the Latin strumosa, f. ("a scrofulous tumor, goiter"), and refers to the unusually bulbous ventral lobe and large L3.

Types: Holotype, a female left valve, no. 34660. Allotype, an incomplete male left valve, no. 34661. Paratype, a female right valve, no. 34662. Unfigured paratype, an incomplete female right valve, no. 34726 .

\section{Genus Subligaculum Kesling and McMillan, 1951}

Type species: Subligaculum scrobiculatum Kesling and McMillan, 1951, pp. 65-66, pl. 2, figs. 1-4; pl. 7, figs. $1-8$, by original designation.

Diagnosis: Hollinid genus with each valve more or less quadrilobate, having L2 and L3 more prominent than $\mathrm{L} 1$ and L4; S2 the only deep sulcus, extending only from the hinge line to the middle of the valve; male with a posterior velate spur and a short anteroventral frill; female with a scalloped frill, the scallops forming cuplike structures but not loculi.

\section{Subligaculum avitum Kesling and Peterson, new species Plate 2, figures 23-24}

Diagnosis: Subligaculum species very similar to the type species, but having each male valve with much lower and less distinct papillae, a conical spur, an unornamented frill, and no furrow from the posterocentral pit to the spur.

Male: Valve subquadrate to subelliptical in lateral view. Hinge line straight, anterior and posterior border bluntly subround, and ventral border gently curved.

L1 a lobe confluent with the ventral lobe, L2 a large knob extending to the hinge line, L3 a low knob posteriorly joined to L4, and L4 a curved lobe along the posterior border. Ventral lobe broad, prominent, extending from $\mathrm{Ll}$ to $\mathrm{L} 4$. Sl short, curved around the anterior border of L2; S2 deep, relatively narrow, curved around the posterior border of L2 but not quite joined to $\mathrm{Sl}$; S3 a deep pit, connected by a narrow furrow to the ventral part of S2. Velate structure developed as an anteroventral frill and a posteroventral spur. Frill narrow and flat, lying parallel to the plane of the contact margin and close to it. Spur subconical to conical, very prominent, projecting outward about as far as the frill. Surface of valve ornamented with very low, small, closely spaced papillae. Frill, spur, and sulci smooth to finely granular.

Dimensions of holotype, a right valve: Length $0.72 \mathrm{~mm}$; height $0.46 \mathrm{~mm}$; width $0.18 \mathrm{~mm}$.

Remarks: This species appears to be a direct ancestor of Subligaculum scrobiculatum Kesling and McMillan, the type species. The two have about the same outline, 


\section{KESLING AND PETERSON}

PLATE 1

All figures $\times 30$.

1-3 Abditoloculina obesivelata Kesling and Peterson, n. sp.

Lateral, ventral, and anteroventral views of holotype, no. 34665, a female right valve.

4-6 Abditoloculina palpebrata Kesling and Peterson, n. sp.

Lateral, ventral, and anteroventral views of holotype, no. 34666, a female right valve.

10-12 Abditoloculina clavicavosa Kesling and Peterson, n. sp.

Lateral, ventral, and anteroventral views of holotype, no. 34667, a female left valve.

13-15 Abditoloculina fundiornata Kesling and Peterson, n. sp.

Lateral, ventral, and anteroventral views of holotype, no. 34668, a female left valve.

7-9, 16-18 Abditoloculina pumila Kesling and Peterson, n. sp.

7-9, lateral, ventral, and anteroventral views of paratype, no. 34670, an almost complete female right

valve; 16-18, lateral, ventral, and anteroventral views of holotype, no. 34669, a female right valve.

19-21 Abditoloculina cavimarginata (Ulrich)

Lateral, ventral, and anteroventral views of topotype, no. 34671, a female right valve.

22-24, 31-34 Abditoloculina repanda Kesling and Peterson, n. sp.

22-24, lateral, ventral, and anteroventral views of holotype, no. 34672, a female right valve; 31-34, lateral, ventral, anteroventral, and anterior views of paratype, no. 34688, a female right valve.

25-27 Abditoloculina eminens Kesling and Peterson, n. sp.

Lateral, ventral, and anteroventral views of holotype, no. 34673, a female left valve.

35-38 Abditoloculina pusilla Kesling and Peterson, n. sp.

Lateral, ventral, anteroventral, and anterior views of holotype, no. 34676, a female right valve.

28-30, 48-49 Abditoloculina prominens Kesling and Peterson, n. sp.

28-30, lateral, ventral, and anteroventral views of holotype, no. 34674, a female left valve; 48-49, lateral and ventral views of paratype, no. 34675, a female left valve.

39-41, 56-59 Abditoloculina insolita Kesling

39-41, lateral, ventral, and anteroventral views of topotype, no. 34677, a female left valve; 56-57, lateral and ventral views of allotype, no. 27779, a male right valve; 58-59, lateral and ventral views of topotype, no. 34678 , a female left valve.

42-47 Abditoloculina binodata Kesling and Peterson, n. sp.

42-44, lateral, ventral, and anteroventral views of paratype, no. 34680, a female right valve; 45-47, lateral, ventral, and anteroventral views of holotype, no. 34679, a female left valve.

50-51 Abditoloculina male, type A

Lateral and ventral views of a male left valve, no. 34681.

52-55 Abditoloculina male, type B

$52-53$, lateral and ventral views of an almost complete male left valve, no. 34682; 54-55, lateral and ventral views of an incomplete male right valve, no. 34683.

62-63, 66-67 Abditoloculina male, type C

62-63, lateral and ventral views of an immature male right valve, no. 34685; 66-67, lateral and ventral views of an adult male right valve, no. 34684 .

60-61, 64-65 Abditoloculina male, type D

60-61, lateral and ventral views of an immature male right valve, no. 34687; 64-65, lateral and ventral views of an adult male right valve, no. 34686 .

68-69 Abditoloculina armata (Ulrich)

Lateral and ventral views of topotype, no. 34652, a male right valve. 


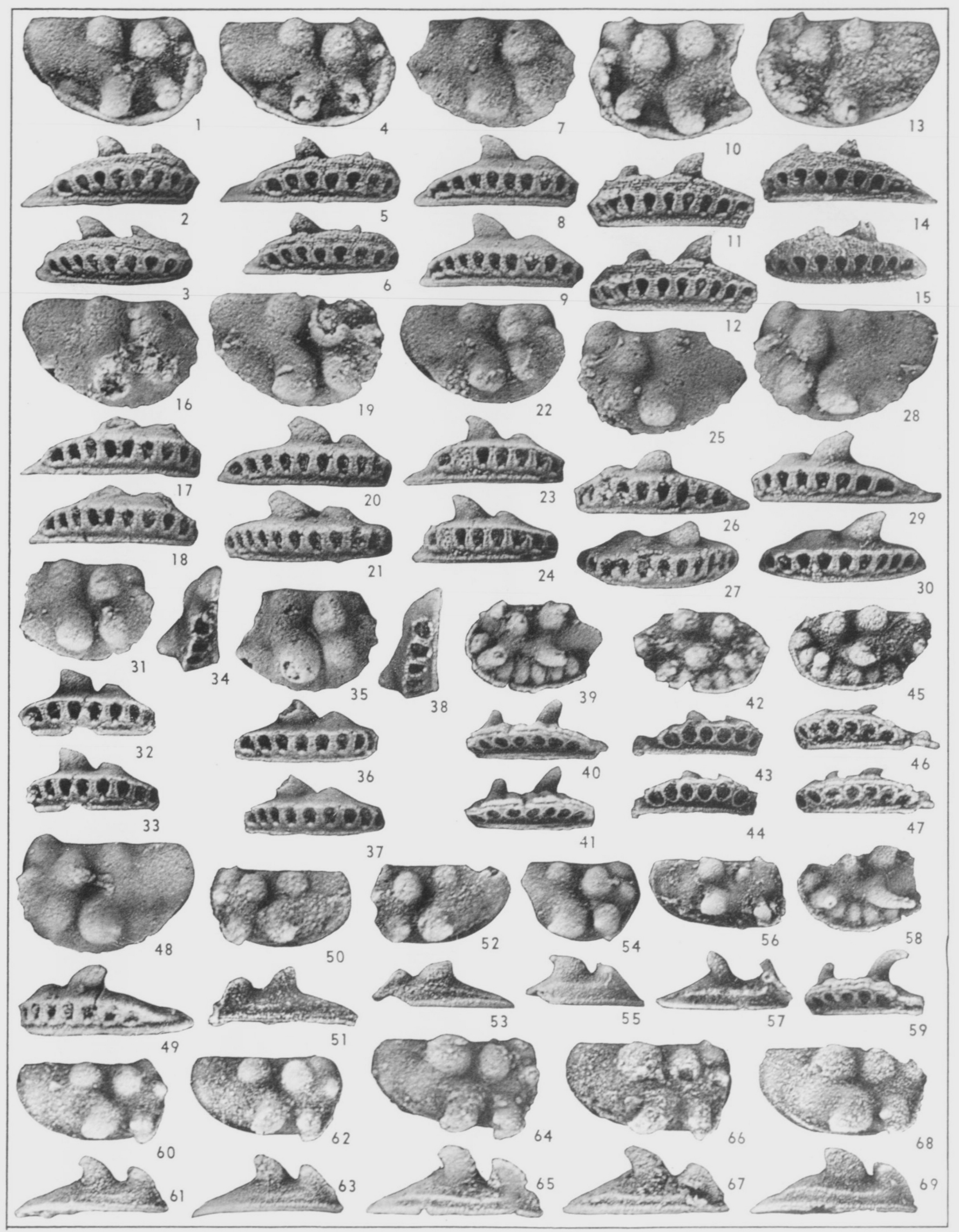




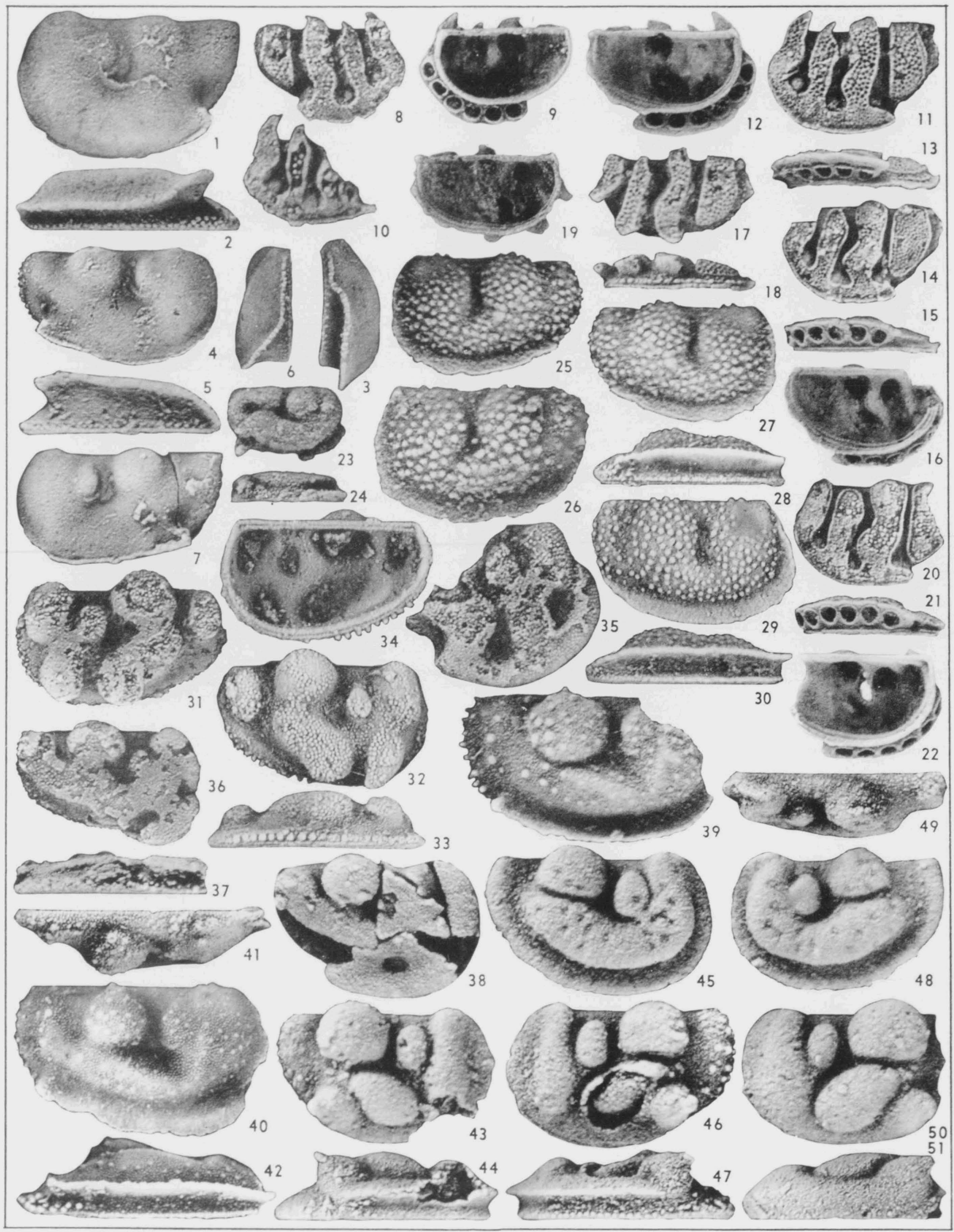


PLATE 2

All figures $\times 30$.

1-7 Flaccivelum informis (Clrich)

1-3, lateral, ventral, and anterior views of topotype, no. 34642, a female left valve; 4-6, lateral, ventral, and anterior views of topotype, no. 34641, a male right valve; 7, lateral view of topotype, no. 34643, a male left valve.

8-13, 17-19 Ctenoloculina exocha Kesling and Peterson, n. sp.

8-9, lateral and interior views of paratype, no. 34646, a female right valve; 10, lateral view of paratype, no. 34647 , an incomplete female left valve; 11-13, lateral, interior, and ventral views of allotype, no. 34645, a female left valve; 17-19, lateral, ventral, and interior views of holotype, no. 34644, a male left valve.

14-16, 20-22 Ctenoloculina platyca Kesling and Peterson, n. sp.

14-16, lateral, ventral, and interior views of holotype, no. 34648, a female left valve; 20-22, lateral, ventral, and interior views of paratype, no. 34649, an almost complete female left valve.

23-24 Subligaculum avitum Kesling and Peterson, n. sp.

Lateral and ventral views of holotype, no. 34650 , a male right valve.

25-30 Adelphobolbina papillosa (Ulrich)

25 , lateral view of topotype, no. 34651, a male left valve; 26 , lateral view of a male left valve; 27-28, lateral and ventral views of topotype, no. 34653, a male right valve; 29-30, lateral and ventral views of topotype, no. 28093, a male right valve.

31-35 Hollina insolens (Ulrich)

31, lateral view of topotype, no. 34654, a male left valve; 32-34, lateral, ventral, and interior views of allotype, UMMP no. 27776, a male right valve; 35, lateral view of topotype, no. 34655, an incomplete female right valve.

36-38 Hollina compressa Kesling and Peterson, n. sp.

36-37, lateral and ventral views of holotype, no. 34656, a male right valve; 38 , lateral view of allotype, no. 34657 , a female right valve.

39-42 Hollinella antespinosa (Ulrich)

39, lateral view of topotype, no. 34658, an incomplete male right valve; 40-42, lateral, dorsal, and ventral views of topotype, no. 34659, a male right valve.

43-44, 46-47, Hollinella strumosa Kesling and Peterson, n. sp.

50-51 43-44, lateral and ventral views of paratype, no. 34662, a female right valve; 46-47, lateral and ventral views of holotype, no. 34660, a female left valve; 50-51, lateral and ventral views of allotype, no. 34661, an incomplete male left valve.

45, 48-49 Hollinella kolmodini (Jones)

45 , lateral view of topotype, no. 34663, a male right valve; 48-49, lateral and dorsal views of topotype, no. 34664 , a male left valve. 
sulcation, and velate structures, but Subligaculum avitum has much lower and less distinct papillae, its frill is unornamented, and it lacks a furrow connecting the posterior pit (S3) with the posteroventral border at the spur.

The name of this species is derived from the Latin avitus ("relating to a grandfather, ancestral"), and refers to its similarity to Subligaculum scrobiculatum, described previously from younger strata.

Type: Holotype, a male right valve, no. 34650.

\section{LITERATURE CITED}

BASSLER, R. S.

1941 - Ostracoda from the Devonian (Onondaga) chert of western Tennessee. Washington Acad. Sci., Jour., vol. 31, no. 1, pp. 21-27, 1. pl.

Bassler, R. S., AND Kellett, B.

1934 - Bibliographic index of Paleozoic Ostracoda. Geol. Soc. Amer., Spec. Paper, no. 1, 500 pp., 24 text-figs.

Campbell, G.

1942 - Middle Devonian stratigraphy of Indiana. Geol. Soc. Amer., Bull., vol. 53, pp. 1055-1072, 2 text-figs.

Coryell, H. N.

1928 - Some new Pennsylvanian Ostracoda. Jour. Pal., vol. 2, no. 4, pp. 377-381, pl. 51.

Coryell, H. N., and Malkin, D. S.

1936 - Some Hamilton ostracodes from Arkona, Ontario. Amer. Mus. Novitates, no. 891, pp. 1-20, text-figs. 1-38.

Ellis, B. F., AND Messina, A. R.

1952 - Catalogue of Ostracoda; Vol. 1. Amer. Mus. Nat. Hist., Spec. Publ., unnumbered pages, loose-leaf, ill.

1954 - Ibid.; Vol. 4.

Grabau, A. W., And Shimer, H. W.

1910 - North American index fossils: Invertebrates; Vol. 2. New York: A. G. Seiler and Co.

JAANUSSON, V.

1957 - Middle Ordovician ostracodes of central and southern Sweden. Uppsala, Univ., Geol. Inst. Bull., vol. 37 (also reprinted as Uppsala, Univ., Pal. Inst., Publ., no. 17), pp. 173-442, 15 pls., 46 text-figs.

JONES, T. R.

1890 - On some Devonian and Silurian Ostracoda from North America, France and the Bosphorus. Geol. Soc. London, Quart. Jour., vol. 46, pp. 534-556, pl. 20.

KAY, G. M.

1940 - Ordovician Mohawkian Ostracoda: Lower Trenton Decorah fauna. Jour. Pal., vol. 14, no. 3, pp. 234-269, pls. 29-34.

Kellett, B.

1929 - The ostracode genus Hollinella, expansion of the genus and description of some Carboniferous species. Jour. Pal., vol. 3, no. 2, pp. 196-217, pls. 25-26.

Kesling, R. V.

1951 - Terminology of ostracod carapaces. Michigan, Univ., Mus. Pal., Contr., vol. 9, no. 4, pp. 93-171, 18 pls., 7 text-figs.

1952 - Dimorphism in Devonian hollinid ostracods of North America. Jour. Pal., vol. 26, no. 5, pp. 764-771, pl. 111, 1 text-fig.

1955 - Two new species of ostracods from the Centerfield limestone of New York. Michigan, Lniv., Mus. Pal., Contr., vol. 12, no. 14, pp. 273-284, 2 pls.
Kesling, R. V., and McMrllan, G.W

1951 - Ostracods of the family Hollinidae from the Bell shale of Michigan. Michigan, Univ., Mus. Pal., Contr., vol. 9, no. 2, pp. 45-81, 7 pls., 2 text-figs.

Kesling, R. V., ANd TABor, N. R.

1952 - Two new species of ostracods from the Genshaw formation (Middle Devonian) of Michigan. Jour. Pal., vol. 26, no. 5, pp. 761-763, pl. 111 .

1953 - Ostracods of the family Hollinidae from the Genshaw formation of Michigan. Michigan, Univ., Mus. Pal., Contr., vol. 10, no. 5, pp. 83-100, 3 pls.

KesLing, R. V., AND Weiss, M.

1953 - Ostracods from the Norway Point formation of Michigan. Michigan, Univ., Mus. Pal., Contr., vol. 11, no. 3, pp. $33-76,5$ pls.

MOORE, R. S.

1929 - Basslerina, a new holliniform ostracode genus with description of new Pennsylvanian species from Texas and Oklahoma. Denison Univ., Sci. Lab., Bull., vol. 24, p. 100.

POKORNÝ, V.

1954 - Základy zoologické mikropaleontologie. Prague: Ceská Akad. Věd, 651 pp., 756 text-figs.

RAYMOND, P. E.

1904 - The Tropidoleptus fauna at Canandaigua Lake, New York, with the ontogeny of twenty species. Carnegie Mus., Ann., vol. 3, no. 1, pp. 79-177, pls. 1-8.

Shimer, H. W., And Shrock, R. R.

1944 - Index fossils of North America. New York: John Wiley and Sons, Inc., pp. 660-693.

Stewart, G. A.

1950 - Ostracoda from Middle Devonian bone beds in central Ohio. Jour. Pal., vol. 24, no. 6, pp. 652-666, pls. 85-86.

Stover, L. E.

1956 - Ostracoda from the Windom shale (Hamilton) of western New York. Jour. Pal., vol. 30, no. 5, pp. 1102-1142, pls. 111-119, 8 text-figs.

Swartz, F. M.

1936 - Revision of the Primitiidae and Beyrichiidae, with new Ostracoda from the Lower Devonian of Pennsylvania. Jour. Pal., vol. 10, no. 7, pp. 541-586, pls. 78-89.

UlRICH, E. O.

1890 - New and little known American Paleozoic Ostracoda Cincinnati Soc. Nat. Hist., Jour., vol. 13, no. 3, pp. 104-137, pls. 7-10.

1891 - Ibid. (concluded). Op. cit., vol. 13, no. 4, pp. 173211, pls. 11-18.

1900 - New American Paleozoic Ostracoda; No. 1 - Ctenobolbina and Kirkbya. Cincinnati Soc. Nat. Hist., Jour., vol. 19, pp. 179-186, pl. 8.

Ulrich, E. O., ANd Bassler, R. S.

1908 - Preliminary revision of the Beyrichiidae, with description of new genera. U. S. Nat. Mus., Proc., vol. 35, pp. 277-340, pls. 37-44, text-figs. 1-61.

1923 - Paleozoic Ostracoda: Their morphology, classification and occurrence. Maryland, Geol. Survey, Silurian, pp. 271 391, text-figs. 11-25.

Warthin, A. S., JR.

1943 - Common Ostracoda of the Traverse group. Michigan, Univ., Mus. Pal., Contr., vol. 4, no. 12, pp. 205226, pl. 1.

1937 - Type invertebrate fossils of North America (Devonian): Beyrichiacea. Philadelphia: Wagner Free Institute of Science, cards 1-105, ill. 
Eleanor S. Salmon

\author{
W. Storrs Cole \\ Jean Cuvillier \\ Georges Deflandre \\ Gunnar Erdtman \\ Martin F. Glaessner \\ N. Grékoff \\ F. R. S. Henson \\ W. S. Hoffmeister \\ Robert V. Kesling \\ Stuart A. Levinson
}

\author{
Alfred R. Loeblich, Jr. \\ Raymond E. Peck \\ Hans H. Renz \\ R. V. Sitholey \\ P. C. Sylvester-Bradley \\ M. L. Thompson \\ Erich Triebel \\ L. R. Wilson \\ Walter Youngquist
}

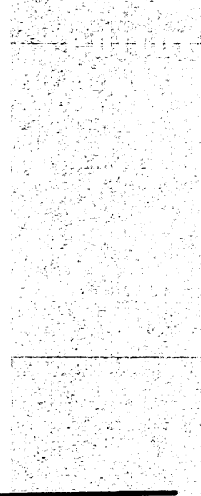

Kiyoshi Asano ...................Japan

Edwin T. Ashworth .................Peru

Tom Barnard ...................... Great Britain

Franciszek Bieda ................. Poland

Esteban Boltovskoy .................. Argentina

Paul Bronnimann ..................West Indies

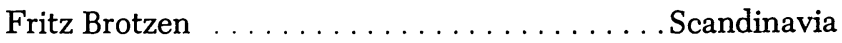

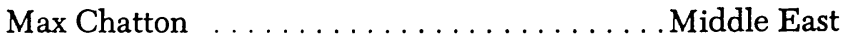

Guillermo Colom .................. Spain

Irene Crespin $\ldots \ldots \ldots \ldots \ldots \ldots \ldots \ldots$ Australia

Jean Cuvillier .................... France

Dorothy J. Echols . . . . . . . . . . . . . . . United States, Mid-Continent Region

A. Suat Erk . . . . . . . . . . . . . . Turkey

Jaime M. Ferreira .................. Portugal

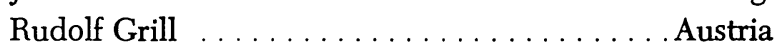

Heinrich Hiltermann..$\ldots \ldots \ldots \ldots \ldots$. . . . . . . . . .

N. de B. Hornibrook . . . . . . . . . . . . . . New Zealand

Robert V. Kesling . . . . . . . . . . . . . . . United States, East-Central Region

Frederico W. Lange .................. Brazil

Stuart A. Levinson . . . . . . . . . . . . . United States, Gulf Coast

Alfred R. Loeblich, Jr. . . . . . . . . . . . . . United States, East Coast

E. di Napoli Alliata . . . . . . . . . . . . Italy

George A. de Neve .................. Indonesia

Viktor Petters ..................... Colombia

S. R. N. Rao . . . . . . . . . . . . . . . India

C. D. Redmond . . . . . . . . . . . . . Saudi Arabia

Manfred Reichel .................. Switzerland

Z. Reiss ..................... Israel

Marcel Rey $\ldots \ldots \ldots \ldots \ldots \ldots \ldots$ North Africa

Arménio T. Rocha . . . . . . . . . . . . Portugal, Overseas Provinces

Rushdi Said ..................... Egypt

R. M. Stainforth . . . . . . . . . . . . . United States, Rocky Mountain Region

Boguslaw J. Szenk . . . . . . . . . . . . . Venezuela

C. Téllez-Girón . . . . . . . . . . . . . . Mexico

Hans E. Thalmann ... . . . . . . . . . . United States, West Coast

J. H. van Voorthuysen ................ Benelux 


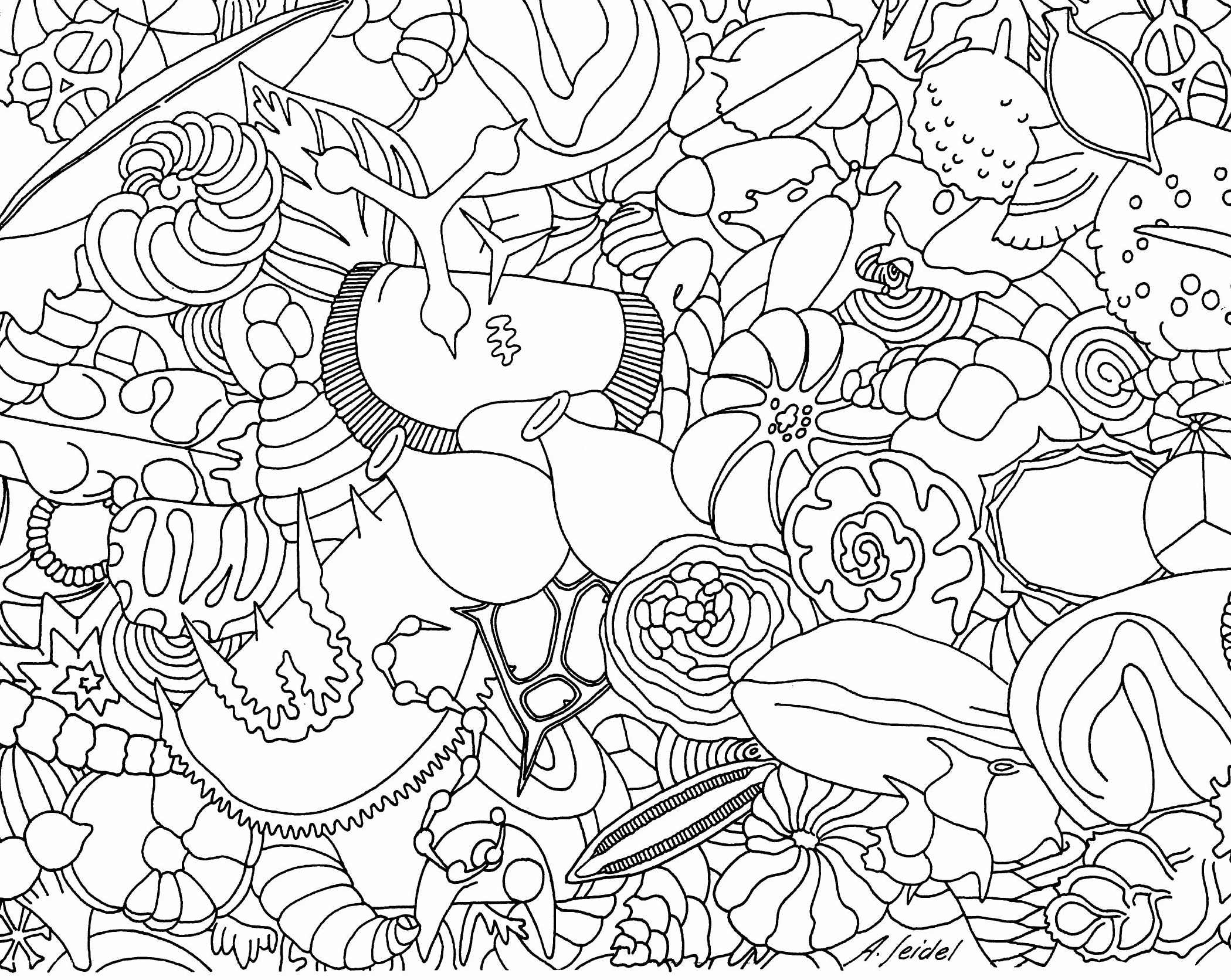

